\title{
Újabb kutatás a kaposszentjakabi apátság területén 2. A 2016-ban végzett régészeti feltárás
}

\author{
MOLNÁR ISTVÁN \\ Rippl-Rónai Megyei Hatókörü Városi Múzeum, H-7400 Kaposvár Fő u. 10., \\ e-mail: molnaristvan74@yahoo.com
}

\begin{abstract}
MOLNÁR I.: Research in the area of the Benedictine abbey, Kaposszentjakab Part 2.

Abstract: The Benedictine monastery was founded in 1061. During the excavations we found the remains of an earlier church and fortification. The earlier buildings of the abbey were situated in the southern and western wing, while towards the East a chapel was built. The quadrum was completed at the turn of the $14-15 \mathrm{C}$. with the reuse of earlier buildings.
\end{abstract}

Keywords: Middle age, Benedictine abbey, cemetery, fortifications, hypocaustum

A kaposszentjakabi bencés apátság maradványait az 1960-as években Nagy Emese vezetésével tárták fel, majd a munkák 2014-ben és 2016-ban vezetésemmel folytatódtak. ${ }^{1} \mathrm{~A}$ 2014-es feltárásról már jelentek meg beszámolók, ${ }^{2}$ ezúttal az 2016-ban végzett munkáról szeretnék röviden írni. Bár a leletanyag feldolgozása még hosszabb időt vesz igénybe és remélhetőleg számos kérdést megválaszol majd, már most is sok újat tudhatunk meg a monostorról. A 2014-es feltárásról készült beszámolóhoz hasonlóan, számos fotót, rajzot közlök Nagy Emese feltárási dokumentációjából, amikből nagyon fontos információk szürhetőek le. Igyekszem egy, az eddigieknél pontosabb alaprajzot is közzétenni az apátságról, ehhez a mai felmérések mellett, Nagy Emese korabeli, a műemléki helyreállítás előtti rajzait is felhasználtuk.

\section{A lelöhely}

A kaposszentjakabi bencés apátság romjai Kaposvár belterületétől keletre találhatóak. Az egykor Zselicszentjakabinak nevezett monostor a Zselici dombvidékének és a Kapos folyó völgyének találkozásánál egy észak-déli irányú meredek dombhát északi végén épült (1. ábra). Alapítólevelének szövege későbbi oklevelekben megörződött. Innen tudjuk, hogy a Győr nembeli Atha (Ottó), somogyi ispán 1061-ben Szent Jakab hegyén alapította monostorát, ahol korábban már volt egy templom, amely „szerfölött régisége

1 A feltáráson a Rippl-Rónai Múzeum dolgozói közül Nyári Zsolt, Stunya Péter, Cserép Tamás és Papp Zoltán vett részt. Köszönetet mondok a feltárás minden résztvevőjének és a feltárás költségét biztosító Kaposvár Megyei Jogú Város Önkormányzatának. A publikációban közölt feltárási rajzokat Nyári Zsolt, a fotókat Stunya Péter és Cserép Tamás készítette. A tárgyfotók és az illusztrációk Balla Krisztián munkái, a tárgyakat Horváth Péter restaurálta. Buzás Gergelynek, Aradi Csillának, Varga Máténak, Költö Lászlónak, Merva Szabinának és Mordovin Maximnak ezúttal is köszönöm a segítségét.

2 Molnár 2014, Molnár 2015. és elhanyagoltsága miatt már pusztán állt." ${ }^{3} \mathrm{~A}$ monostor nagy adományokat kapott, felszenteléséröl - amely Salamon király és Géza herceg jelenlétében, valószínüleg 1067-ben történt - a Képes Krónika is megemlékezett. A középkor folyamán a Dél-Dunántúl egyik legfontosabb bencés rendháza volt, több mint 60 településen voltak birtokai, bár gazdagságát a kegyúri család erős befolyása korlátozta. A korabeli írott források leginkább a kegyuraságot birtokló Győr nembeli Szerdahelyi család különböző ágainak az apátsággal és egymással való pereskedéseivel és egyezkedéseivel kapcsolatosak. A monostor 1392-ben búcsúengedélyt kapott. Az 1508as bencés vizitációból tudjuk, hogy az apáttal együtt 6 szerzetes élt az apátság akkor még jó állapotban lévő épületeiben. A török veszély miatt, legkésőbb 1543-ra a szerzetesek elhagyták a kolostort és helyükre katonák érkeztek. Az épületegyüttes rövid ideig végvárként müködött, majd 1555-ben Kaposvár várával együtt török kézre került. ${ }^{4}$

1960-66 között Nagy Emese vezetésével folytak régészeti feltárások a területen. A résztvevőknek hatalmas mennyiségü földet kellett eltávolítaniuk, hogy a falak maradványait kiszabadítsák. A feltárások során bebizonyosodott, hogy a dombot már a bronzkorban és a római korban is lakták. Megállapították, hogy a monostortemplom jórészt az 1060-as évekbeli formájában maradt meg, a négyszögletes udvar és kerengőfolyosó köré emelt kolostori épületek a 14-15. század fordulóján, míg az északra található centrális szerkezetű plébániatemplom a 13. század végén épülhetett. ${ }^{5} \mathrm{~A}$ feltárás közben már folyt a Zádor Mihály vezette müemléki helyreállítás, aminek végére nagyjából kialakult a romkert mai formája (2. ábra). Sajnos a feltárásról csak rövid beszámolók jelentek meg. ${ }^{6}$ A korabeli feltárási dokumentáció számos fontos információt tartalmaz, ${ }^{7} \mathrm{de}$ nem mindent rajzoltak, fotóztak le kellő részletességgel. A kutatott részeken is maradtak feltáratlan területek, általában nem érték el a bolygatatlan altalajt. A különböző korú falakat nem mindig különítették el egymástól.

3 Kumorovitz 1964

4 A kolostor történetéröl bővebben: Zádor 1964. 28-37., 45-48., Győrffy 1975. 66-67, Komjáthy 1975. 75-76., Magyar 1981, 3-8., Hervay 2001. 527., M. Aradi 2016. 178-180.

5 Nagy 1973

$6 \quad$ Nagy 1973., Nagy 1978., Nagy 1994.

7 A Rippl-Rónai Megyei Hatókörü Városi Múzeum adattára 662-666. A dokumentáció néhány, elsősorban a monostortemplommal kapcsolatos rajza, fotója már közölve lett: Molnár 2014. 189-193. 


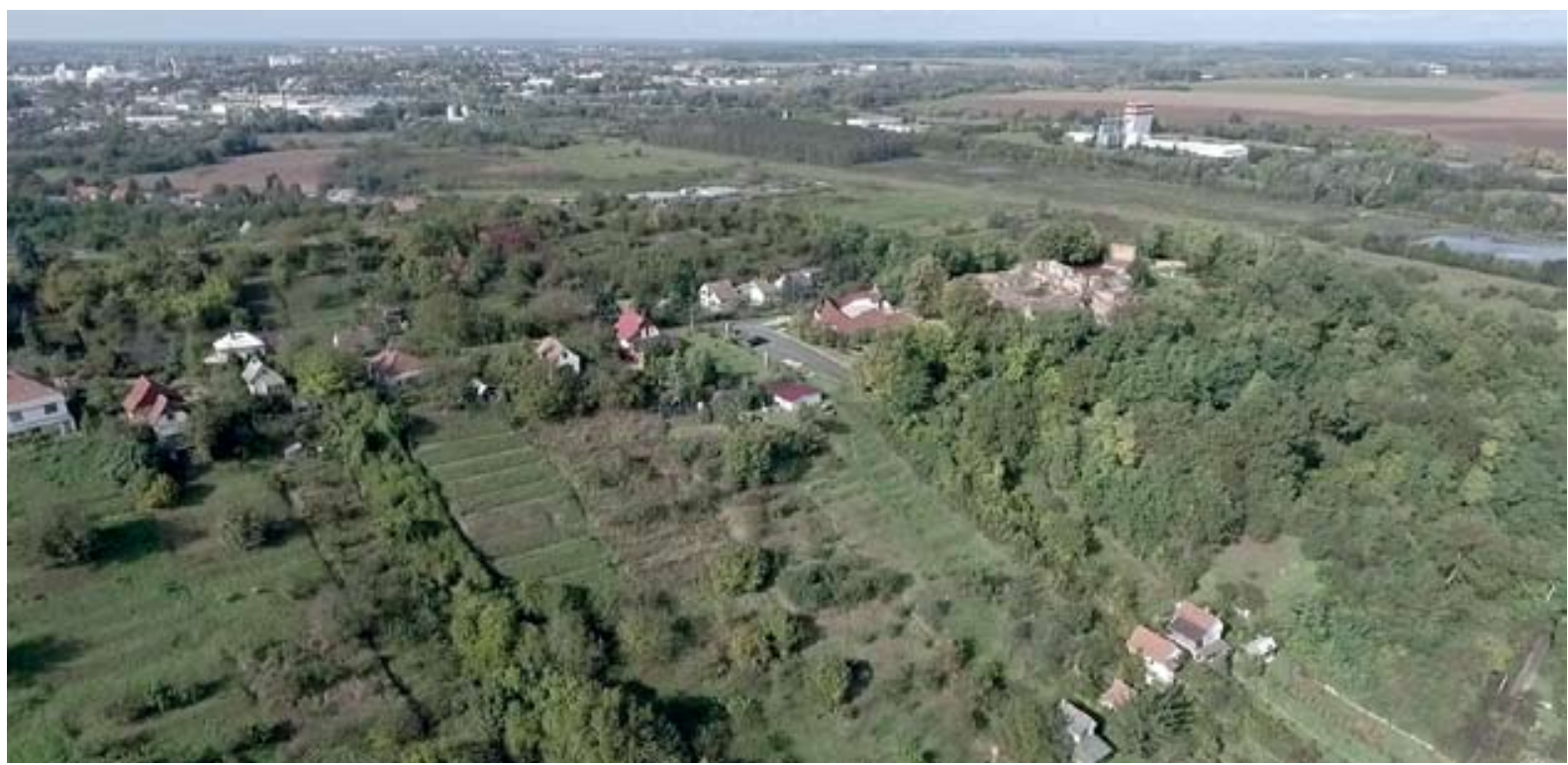

1. ábra. Drónfelvétel a monostor környezetéröl. A kép jobb oldalán a dombtetön épült monostor maradványai, háttérben Kaposvár városa, a kép jobb szélén a Kapos folyó. (Borzavári Balázs felvétele)

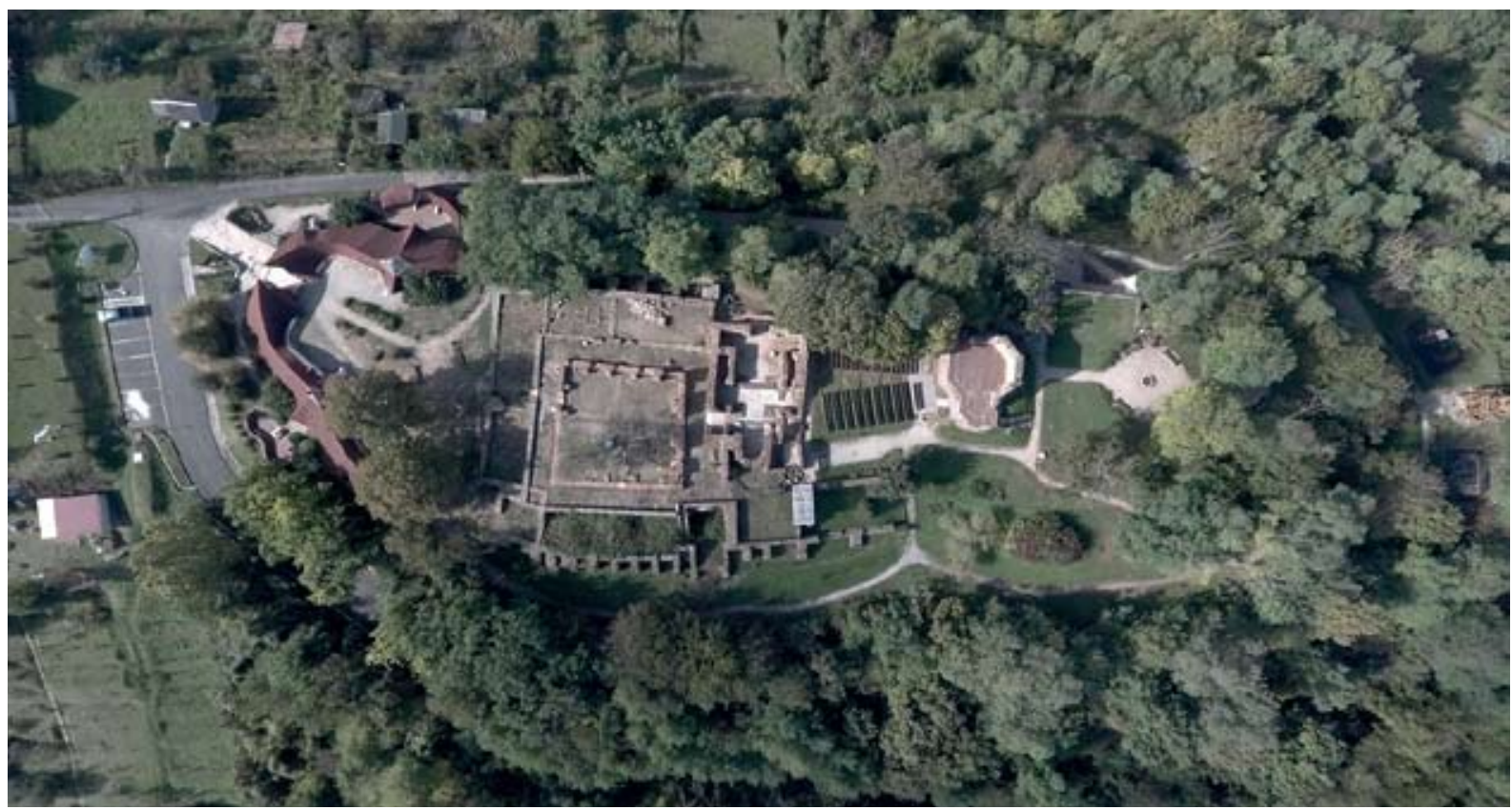

2. ábra. Drónfelvétel az apátság maradványairól (Borzavári Balázs felvétele)

A szükségessé váló állagmegóvó munkálatok előtt, 2014-ben újra feltártuk a monostortemplom területét. Megállapítottuk, hogy a ma látható falak legalább 3 korszakból származnak. A monostor alapítása előtt itt álló templom maradványait is felhasználták az 1060-as évekbeli építkezéskor, majd később (feltehetően a gótikus átépítés során) is újabb falszakaszok készültek. A templomtól keletre, délkeletre lévő terület kutatása közben megállapítható volt, hogy a kolostor épületi is több korszakban épültek. ${ }^{8}$

8 Molnár 2015.

\section{A 2016-ban végzett feltárás}

A romkert mellé tervezett látogatóközpont építése illetve a kolostori épületeket érintő állagmegóvás és részleges helyreállítás előtt, 2016-ban folytattuk a feltárást, amelynek költségét Kaposvár Megyei Jogú Város Önkormányzata bocsátotta rendelkezésünkre. A munka elsősorban a tervezett építkezések által érintett területekre terjedt ki, emellett - amennyire lehetséges volt - igyekeztünk információt szerezni a kolostori épületek periodizációjára is (3. ábra). Első lépésben az újkori, jórészt a 60-as években visszatemetett rétegeket kel- 


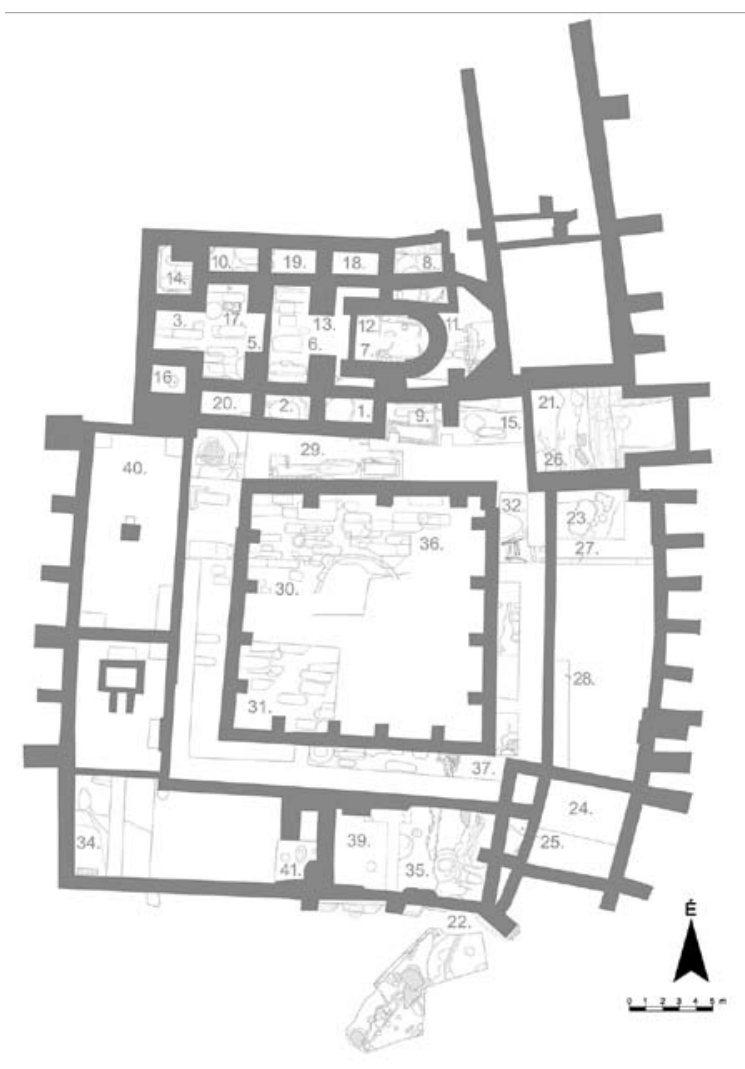

3. ábra. A feltárási szelvények helye. (A Meridián kft felmérésének felhasználásával készült alaprajz a romterület jelenlegi, a müemléki helyreállitás utáni állapotát ábrázolja)

lett eltávolítanunk, ami alatt változatos vastagságban megmaradt régészeti korú rétegeket, objektumokat találtunk. Feltárásuk mellett, az alapfalak dokumentálása volt az ásatás elsődleges célja.

A tervek szerint a látogatóközpontot a mai fogadóépület és a kolostor déli szárnya között fog megépülni, ezért a 22. szelvényt itt nyitottunk. ${ }^{9}$ Mivel a területet vastag újkori rétegek fedték, ráadásul a füvesítés előtt lerakott geotextil kézi szerszámokkal nem volt felszedhető egy kisméretű kotróval távolítottuk el a legfelső réteget. A keleti oldalon feltártuk egy az apátságnál korábbi erődítés maradványait, amelyet a területen álló fák és a kolostor déli zárófala között nagyjából 10 méter hosszan követtünk. Nyugaton semmit nem találtunk, a korábbi feltárás és az építkezések a sárga altalajig megsemmisítették az esetleges középkori rétegeket. A fogadóépület melletti területen két kis kutatószelvényt nyitottunk, ahol kb. 2-3 méteres mélységig (ameddig a kis kotró kanala leért) újkori bolygatott rétegeket találtunk.

A keleti kolostorszárny helyiségei mélyebben, a domb oldalában indulnak. A középső, legnagyobb épületben eredetileg kiállítóhelyet, kőtárat is terveztek, így fontos volt megállapítanunk, hogy a középkorban volt-e helyiség az alsó szinten. Az északi részén a 23.

9 Az 1-20. szelvényeket 2013-14-ben tártuk fel, a szelvények számozását így 21-től folytattuk. majd a 27., a nyugati falnál 28. szelvényt jelöltük ki. Itt is (ahogy a keleti kolostorszárnyban mindenhol) megtaláltuk a korai sánc feltöltött padkáját, a ferde domboldalt, de nyilvánvalóvá vált, hogy csak magasabban, a kerengővel egy szintben alakítottak ki helyiséget. A délkeleti helyiségben a 24., az ettől nyugatra lévő kis területen a 25. szelvényt jelöltük ki.

A keleti kolostorszárny északi részén lévő, mélyen a domboldalon induló boltozatos épület részleges visszaállítását tervezik, eredeti funkciójának megállapítása miatt teljes területét újra feltártuk. A 21. és 26. szelvényeket jelöltük ki itt, úgy vélem, az eddigi elképzelésekkel szemben a helyiség nem pince, hanem egy kápolna lehetett.

A déli szárny nyugati részén volt a 34 . szelvényünk, de itt a sárga altalajig újkori visszatöltést találtunk. A déli szárny keleti felében a 35., 39. és 41 . szelvényt nyitottuk, a korai sánc egy szakaszát és egy régi helyiség alapfalait tártuk fel, de a középkori réteget már alig találtunk. A 34. és 41. szelvény közötti terület feltáratlan maradt. A nyugati szárnyban csak kisebb kutatószelvényeket (40. szelvény) nyitottunk a falak alapozását vizsgálva.

Feltártuk a kerengő jelentős részét, sajnos az újkori beépítések - elsősorban a kerengőt jelképező faépítményt tartó betontuskók sora - nagyobb területek kutatását megakadályozták. Az északi kerengőfolyosó középső és nyugati részén a 29. szelvényt jelöltük ki, az erösen rombolt keleti része nem lett újra feltárva. A keleti folyosóban 32. és 38., a nyugatiban a 33., a déliben a 37. szelvényt nyitottuk. A kerengőfolyosót változó mértékben tárták fel a 60-as években, volt ahol alig bolygatták, máshol már csak újkori visszatöltést találtunk.

A kolostorudvar DK-i negyedét az ott álló fa, középső sávját betonsávok és egy vízvezeték árka miatt nem tudtuk megásni, a többi területen a 30., 31. és 36. szelvényeket jelöltük ki. Itt is betontuskók akadályozták nagyobb területek feltárását.

\section{A korai templom keltezése}

2014-ben a monostortemplomban megtaláltuk az alapítólevélben is említett, az apátság alapításakor már a területen álló templom maradványait. A 7,5×12-13 méter nagyságú, egyhajós, egyenes szentélyzáródású templom nagyméretű római téglákból épült, alapozásához nagyobb köveket használtak. Felmenő falainak egy részét felhasználták a monostortemplom építésénél, ilyen falszakaszok a monostortemplom északi belső falainál azonosíthatóak. ${ }^{10}$

A templom keltezését segíti, hogy temetkeztek köré, hiszen az apátsági templom falai már sírokat romboltak. Ugyanakkor a korai templomot nem előzte meg a temető, ennek alapfalai sehol nem metszenek temetkezéseket, pedig sekély alapozásuk biztosan nem tüntette volna el ezek nyomát. ${ }^{11}$ Sajnos az egykori sírok jelen-

10 Molnár 2015. 81-87.

11 A korai templom belseje a monostortemplomba került, ahol a későbbi temetkezések szétrombolták. Ugyanakkor két területen, monostortemplom kórusrekesztője és diadalíve alatt megörződött az egykori talaj. A régi templom belsejét észak-déli irányban keresztező sávoknál szintén nem találtuk korábbi sírok nyomat, ami arra utal, hogy csak a korai épület mellé kezdtek temetkezni. 
tős részét megsemmisítették a későbbi temetkezések, építkezések, ráadásul - mivel melléklet nélküliek voltak - biztonsággal csak azokat tudjuk közülük azonosítani, amelyeket rombolnak az 1060-as években épülő apátsági templom falai. ${ }^{12}$ 2016-ban három ilyen sírból származó csontokon végeztettünk rádiokarbon vizsgálatot. Az eredmények szerint a temetkezések mindenképpen honfoglalás előttiek, valamikor a 8-9. században létesültek, ami alapján leginkább egy 9 . századi templomra gyanakodhatnánk. ${ }^{13}$ Ugyanakkor meg kell említeni, hogy téglából épített templom nem ismert a Karoling birodalom területéröl a 9 . században. ${ }^{14}$

\section{A korai erődítés}

Sikerült feltárnunk egy, a monostornál korábbi erődítés maradványait is. Sajnos az apátság épületei, sírjai, illetve a 60-as évek feltárásai, helyreállításai általában rombolták, így csak egymástól elkülönült kisebb-nagyobb szakaszokat bonthattunk ki, ezekből kell formáját - a lehetőségekhez képest - rekonstruálnunk. Már 2014-ben megtaláltunk egy rövid szakaszát, de a későbbi épületek miatt ott nem tudtuk teljesen feltárni, ezért ezt ekkor árokként és belső oldalán lévő cölöpsorként értelmeztem. 2016-ban tisztáztuk valós szerkezetét.

A ferde domboldalba több sorban 1,5-2 méter mély, vízszintes aljú, nagyjából függőleges falú padkákat ástak, erre faszerkezetet építettek. A nagyjából egyenes szakaszokból álló sánc körbefogta a dombot. A felső, 2-2,5 méter széles padkákból álló szint követi a domb vonalát, így délre haladva szakaszai egyre mélyebben vannak. Az alsóbb szint, 3,5-4 méter széles padkákból álló szakaszai viszont többé-kevésbé egyforma tengerszint feletti magasságon követik egymást. A két szint között délen így csak 2-2,3 méter a szintkülönbség, lépcsőzetesen vannak egymás mögött. A szelvényünk déli végében a felső szint véget is ér, hiszen innentől a domb lejtőjén már csak az alsónak van helye (6. ábra). Északra (a domb magasabb része felé) haladva egyre nő a padkák közti szintkülönbség, a templom előtt már közel 4 méter. Elvileg itt egy köztes szintet is kialakíthattak volna, de mivel a kolostori épületek erősen rombolták az érintett területet, erről nem tudok biztosat mondani. A keleti szárny középső részén (ahol majdnem 3 méter volt a két padka között) még biztosan nem volt ilyen, a padkák között csak a ferde domboldalt találtuk meg $(4,5$. ábra)

12 A 60-as évek feltárásai során is számos információ elveszhetett nem minden sírt rajzoltak, fotóztak, de így is felfedezhettünk a fényképeken az apátsági templom fala által metszett sírt.

13 A mérést az Isotoptech Zrt - MTA Atomki Laboratóriuma végezte (DeA-8902, DeA-8903, DeA-10069). A kapott eredmények alapján a sírok 95\%-os valószínüséggel a következő értékek közé esnek 32. sír: 775-886, 55. sír: 680-859, 111. sír: 721-883. Az eredmények alapján, a 9. század mellett a 8. század is szóba jöhetne, de utóbbi időszakra nehéz lenne szilárd építőanyagú templomot valószínűsíteni.

14 Erre Szőke Béla Miklós hívta fel a figyelmemet, segítségét ezúttal is köszönöm.



4. ábra. A korai sánc padkáinak feltételezhető helye

Magából a faszerkezetből kevés elszenesedett gerenda és néhány faszénsáv maradt (7. ábra). Szerencsére a gerendák több helyen benyomódtak a padkák löszös aljába, így a fekvő helyzetűekre hosszú, ívelt aljú „árkocskák,” az állókra sekély, kör alakú mélyedések utalnak, máskor a padka oldalának nyomódva hagytak nyomot (6. és 8 . ábra). Leégésekor a padkák alján vörösre égett foltok, az oldalukon ívelt, vörösre égett sávok maradtak.

Az épített kazetták 1,8-2 méter szélesek és kb. 3,5-4 méter hosszúak voltak. A felső szinten csak egy sor lehetett belölük, az alsó szinten akár két kazetta is elférhetett volna, de az általunk kutatott területen határozott nyomát csak a falnál állónak találtuk meg. A faszerkezetet stabilitása miatt több helyen a padkák aljába és oldalába is bekötötték. Elöbbiröl $25-40 \mathrm{~cm}$ átmérőjü cölöphelyek, utóbbiról 30-40 cm-re a falba vájt vízszintes cölöpnyomok tanúskodnak (8. ábra). Ezen kívül legalább 80-100 cm mélyen vízszintesen fekvő gerendákat vertek a domboldalba. Több volt egymáson, nem a padkák aljától, hanem valamivel fentebb indultak, kétszer is párosával találtuk őket (9. ábra).

A felső szint felett a domboldalon cölöpsor futott, amit 2014-ben cölöpfal nyomának gondoltam. Ugyanakkor 2016-ban egy helyen a padka külső oldalán (azaz a két padka között) is megtaláltuk ezt cölöplyuk-sort, talán ez is a faszerkezet stabilabb bekötését szolgálta. 


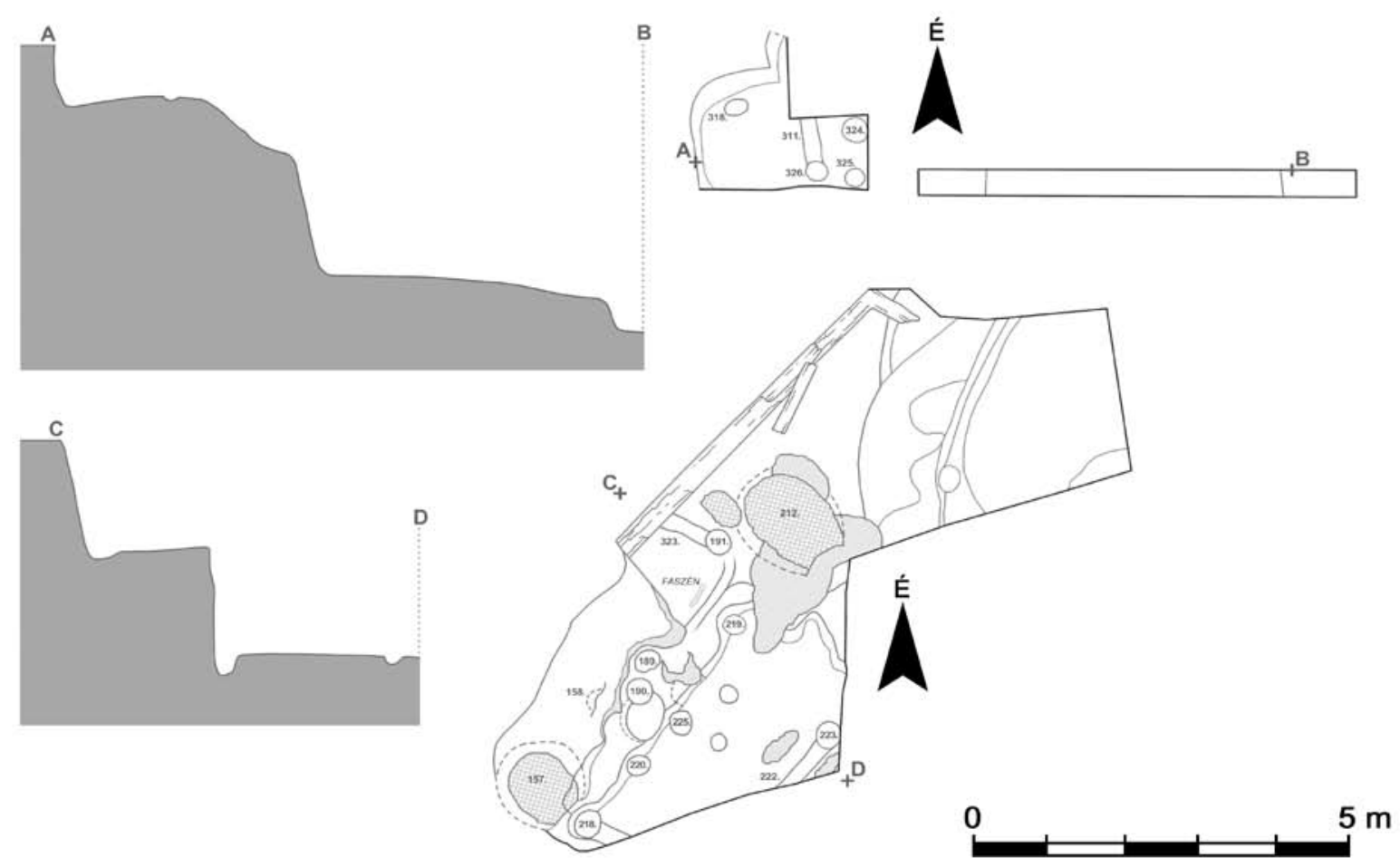

5. ábra. A sánc 26., 32. és 22. szelvényben feltárt szakaszainak felszín- és metszetrajza

Magyarországon az erődítéshez leginkább hasonlót Hontról ismerünk, ahol szintén a ferde dombon kialakított egyenes padkára építették a keskeny, a domboldalba vízszintes gerendákkal bekötött sáncokat. ${ }^{15}$ Hasonlóak még Kijev korai sáncai, ahol a lépcsőzetesen kialakított padkákra épített faszerkezet a ferde domboldalhoz támaszkodott, oda gerendákkal kötötték be. ${ }^{16} \mathrm{Az}$ erődítés viszonylag különleges szerkezete Szentjakabon jól magyarázható a földrajzi körülményekkel. Egy „hagyományosabb” szerkezetü, szélesebb sánc a dombtető jelentős részét elfoglalta volna, a meredek domboldalra viszont csak vízszintes felületek, padkák kialakítása után lehetett építeni. A dombtető alatt induló, nyilván több méter magas sánc, a meredek domboldallal együtt igen hatékony védelmet jelenthetett. A hasonló erődítések viszonylagos ritkaságát az is magyarázhatja, hogy az így készült sáncoknak a pusztulás után alig marad nyoma. Szentjakabon sem volt a régészeti feltárásokig semmilyen látható jele, elképzelhető, hogy hazánkban még számos hasonló módon készített erődítés rejtőzhet meredek domboldalakon.

A meredek domb északi végét - ahol később az apátság is épült - egy mély árok választja el a domb többi részétől. Ma már parkoló és fogadóépület van itt, de a 60-as évek szintvonalas felmérésén és a 60-as, 70-es évek légifotóin még jól látszik korábbi formája. Régészeti kutatás sajnos nem folyt itt, így nem tudjuk,

15 Mordovin 2013. A feltáró az erődítést a 11. századra datálta. 16 Mihajlov 2010. hogy természetes vagy mesterséges képződmény, illetve ez utóbbi esetben milyen korú. ${ }^{17}$

Magának a sáncnak a keltezésekor figyelembe kell venni, hogy pusztulása a megszokott szerkezetűekhez képest másképp történik. Leégésekor a faszerkezetet kitöltő föld jórészt leborult a domboldalon, majd a padkák „árokszerüen” kezdtek feltöltődni. A néhol 3-4 méter máshol csak $30 \mathrm{~cm}$ magasan megmaradt rétegsorából szerencsés esetben elkülöníthetőek az egykor faszerkezet közé töltött föld maradványai, a pusztuláshoz kapcsolódó és az ez utáni feltöltődési rétegek, majd a beásott Árpád-kori objektumok (6. ábra). Szerencsére viszonylag bő leletanyagot találtunk, a kerámiaanyag vizsgálata remélhetöleg eredményre fog vezetni, addig is egyéb kormeghatározási módszerekre támaszkodhatunk. A gerendákból talált égett darabok dendrokronologiai vizsgálatra nem alkalmasak. Az egyiken rádiokabon vizsgálatot végeztettünk, ez alapján annyit tudunk, hogy a 8. századnál nem lehet korábbi a szerkezet. ${ }^{18} \mathrm{~A}$ sánc pusztulásakor megégett növényi maradványok - egy nagyobb adag feldolgozott köles és különösen egy körte maradványai (magok, magház és gyümölcshús szenült maradéka)

17 A területen két bronzkori (a Mészbetétes kultúra illetve az Urnamezős kultúra időszakába tartozó) település is volt - mivel ebbő a korszakból több hasonló, a magasan fekvő dombvégröl árokkal leválasztott erődítés ismert - akár ahhoz is tartozhatna. Ebben az esetben, a középkorban csak felhasználták volna az őskori árkot annak belső oldalánál is megépitve a padkákra épülő sáncokat.

18 A mérést az Isotoptech Zrt - MTA Atomki Laboratóriuma végezte (DeA 9495). A vizsgálat 95\%-os valószínűséggel 694-861 közé datálta a fa kivágását, ami már csak az old wood effect miatt is terminus post quemet jelent. 


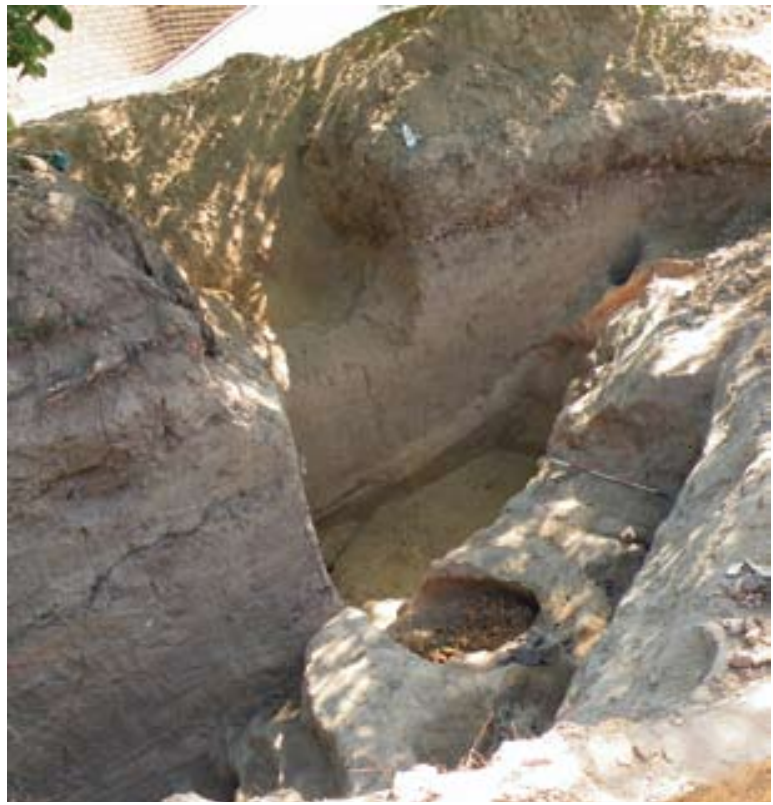

6. ábra. A korai sánc építésekor a dombba ásott padkák maradványai

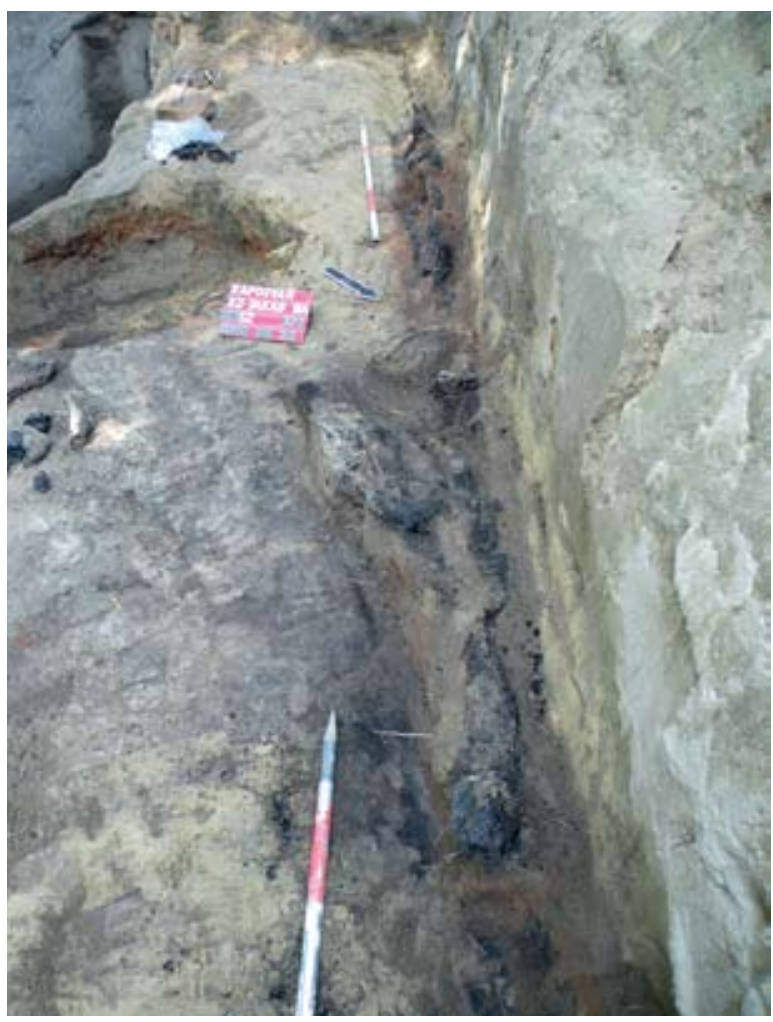

7. ábra. A sánc faszerkezetének égett maradványai

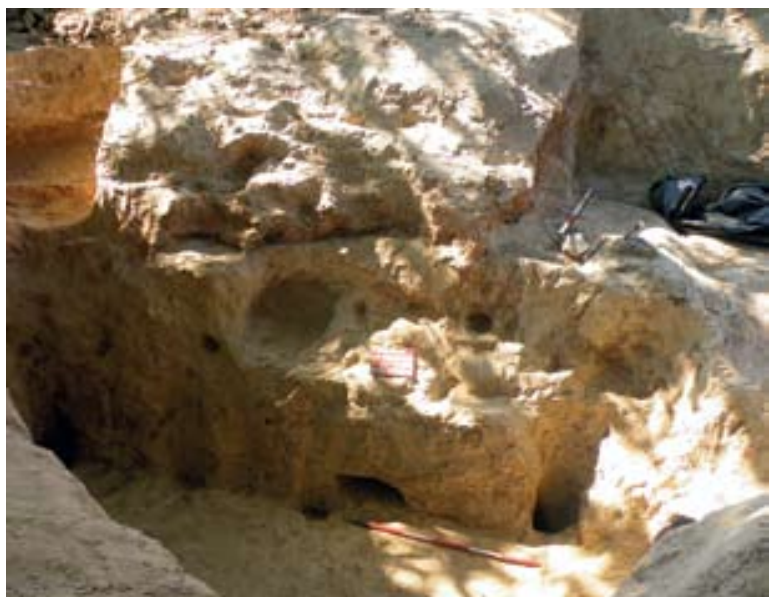

8. ábra. Az alsó padkán álló kazetta nyomai.

A szerkezet stabilitását szolgálták a padka alján lévő függőleges és az oldalába ásott vízszintes cölöphelyek, a padka oldalán a gerendák ívelt lenyomata volt felfedezhető

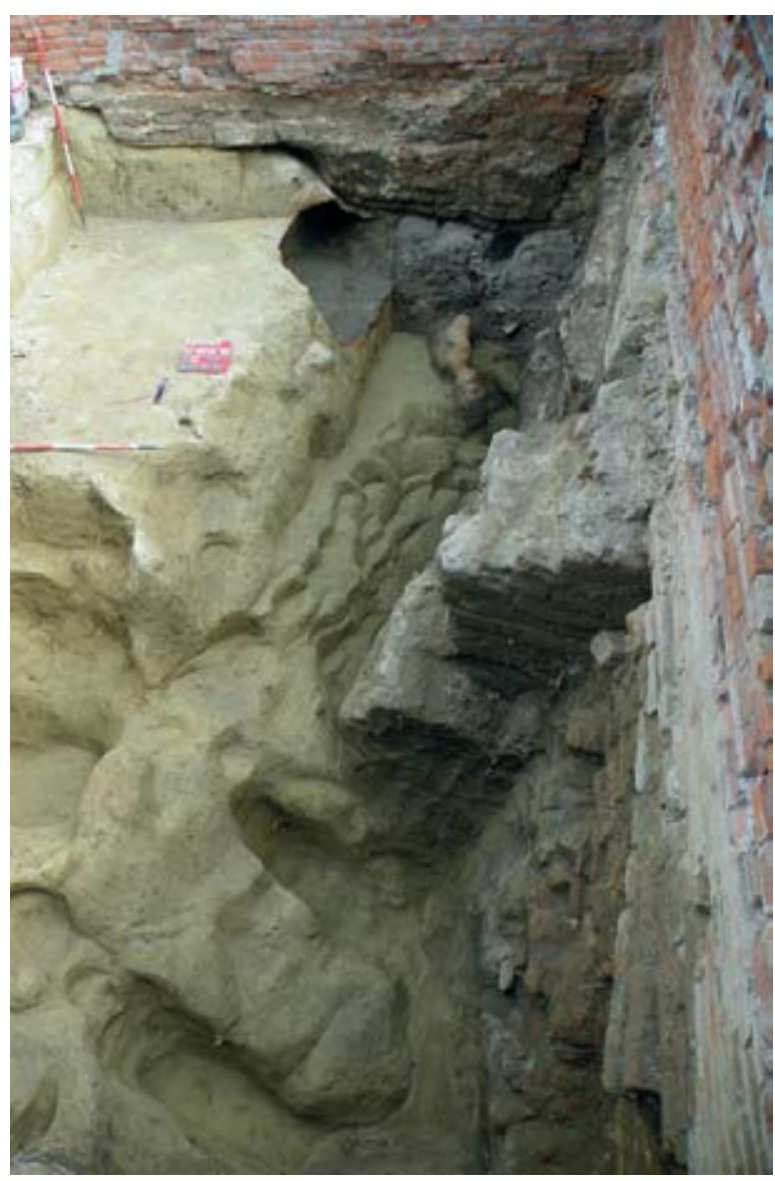

9. ábra. A faszerkezet domboldalba való bekötését szolgáló, párosával álló vízszintes gerendák nyomai 


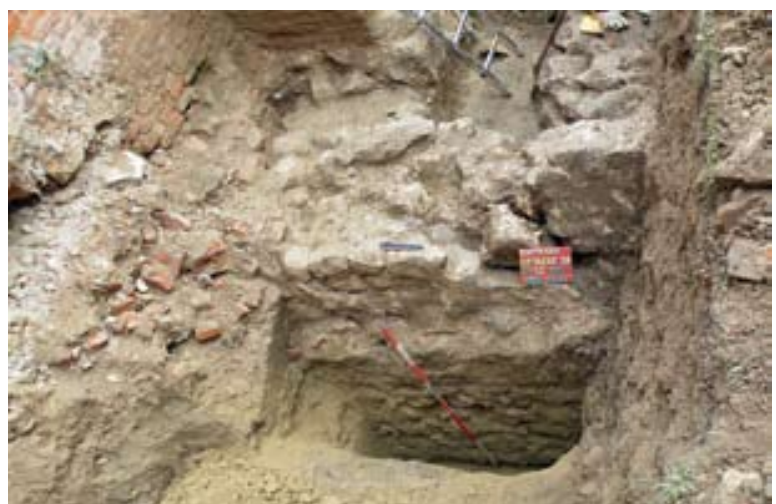

10. ábra. A keleti domboldalban lévő korai támfal maradványai

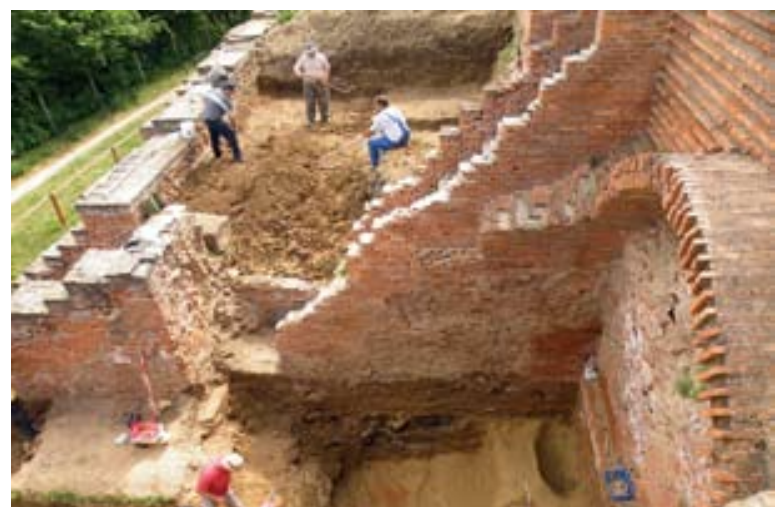

11. ábra. A keleti szárnyban lévő kápolna romjai, a helyiség közepén a korai sánc maradványai látszanak

- a pusztulás idejére szolgáltatnak információkat. A kormeghatározás alapján a sánc a 10 . század utolsó harmada előtt már biztosan elpusztult. ${ }^{19}$

A pusztulás után a részben feltöltődött padkák oldalába kemencéket ástak, amelyek később, a további feltöltődés során eltemetődtek. Két kemence platniján archeomágneses kormeghatározás végeztettünk, az eredmények alapján legkésőbb a honfoglalás utáni évtizedekre már elpusztult a sánc. ${ }^{20}$

Ha a természettudományos vizsgálatok eredményét elfogadjuk, valahová a 8-9. századra kell tennünk az erődítés korát, de nem tudjuk ezen belül mikor, menynyi ideig müködött. Az időszak nagyrészt megegyezik a templom melletti sírok kapcsán kapott értékekkel. Feltételezhetjük, hogy legalább részben egykorúak, még ha biztosan ezt nem is jelenthetjük ki. A komoly munkával megépített sánc és a templom építőanyaga is jelentős helyre utal, ezt alátámasztják a padkák feltöltődésében előkerült aranytárgyak (egy kis aranykarika és egy arany függődarab) is (12. ábra/2-3.). A dombon egyéb

19 A növényi maradványokat Gyulai Ferenc határozta meg, segítségét ezúttal is köszönöm. A mérést az Isotoptech Zrt - MTA Atomki Laboratóriuma végezte (DeA 10089, 10091). Koruk 95\%-os valószínüséggel 776-964 illetve 776-967 közé esik. Mivel a körte mindenképpen frissen égett meg, így ez az intervallum adná meg a sánc pusztulását is.

20 A méréseket Pethe Mihály végezte, a kemencék utolsó használatára, a 157. kemencénél 897+-17, a 212. kemencénél 899+-17 évet kapott. épületek is állhattak, amelyeknek nyomai az apátság építkezései és a sírok ásása során megsemmisülhettek, de a domb még fel nem tárt részén is lehettek. A Kapos völgyében a 8. század végétől, 9. század elejétől jelentős népességkoncentráció figyelhető meg. ${ }^{21}$ A lelőhely közvetlen környékén, 2-3 km-en belül, dombról is jól látható helyeken három korabeli temetőt ismerünk. Jelenlegi ismereteink szerint két a 8 . században induló, majd a 9. században is tovább müködő, és egy 9 . században nyitott temetővel számolhatunk. ${ }^{22} \mathrm{~A}$ dombon lakó személyben talán a népesség vezetőjét sejthetjük.

\section{A monostor első évszádainak építkezései}

A sánc pusztulása után ásott kemencék a település részleges továbbélésére utalnak. Az alapítólevélből is tudjuk, hogy a 11. század közepén is laktak a dombon. Feltehetően nem is kóbor, ,jogcím nélküli” népesség élt itt, hiszen az alapítótól kapott földre költöztették őket. A dombot Szent Jakab hegyeként nevezték, a templom védőszentje is ismert volt még. A helyben lakók is emlékezhettek rá, földrajzi névként is megőrződhetett, de valamilyen egyházi központban is számon tarthatták. A régi templom helyén való monostor alapításának ötletét Atha lelki atyáktól (nyilván művelt egyháziaktól) kapta. ${ }^{23}$

Az 1067-ben felszentelt monostortemplom építésekor felhasználták a régi templom északi és déli oldalfalait. Egy külső falain lizénákkal tagolt, félköríves apszisú, $18,5 \times 12,5$ méter nagyságú épületet emeltek, amelynek közepén négy nagy pillér tartott egy boltozott tér feletti tornyot. Északon és délen karzatos mellékterek épületek, a nyugati karzat fölött torony vagy toronypár álhatott. A szentély előtti palmettás oszloplábazatok diadalívhez, a két nyugati nagy pillér közötti sekély alapozás kórusrekesztőhöz tartozhatott. ${ }^{24}$

\section{Szöke 2007. 52.}

22 Kaposvár-40-es őrház lelőhelyen Eugénia Szimonova majd Bárdos Edith tárt fel temetőrészletet. (Szimonova 1997. Bárdos 1978.) Szimonova rövid beszámolójában késő avarkorra illetve 8. század végére, 9. századra keltezte a temetőt (Szimonova 1997. 41.) A Bárdos Edith által feltárt sírokról jelent meg bővebb beszámoló, Ő a késő avar népesség 9. századi továbbélésével számolt (Bárdos 1978.42-43.) később 8. századi, 9. századba is átnyúló temetőként értékelte (Bárdos 1985. 11.). Kaposvár-Fészerlakpusztánál Eugenia Szimonova tárt fel egy temetörészletet, amely közölve nincs, de feltárója az elöbbi lelöhely legközelebbi párhuzamaként említi (Szimonova 1997. 39.) és Bárdos Edith is azzal egykorúnak gondolja (Bárdos 1985. 11.) Nyugatra, Kaposvár-61-es út lelöhelyen Bárdos Edith egy újabb temető 87 sírját tárta fel. $A z$ eredeti sírszámot 100 körülinek becsülte, úgy vélte a temetkezések a frank győzelem után, a 9. században kezdődtek és magyar honfoglalással érték véget (Bárdos 1985.)

23 Az oklevél szerkesztőjeként, írójaként említett György püspököt az oklevél formai és tartalmi elemei alapján - Kumorovitz Bernát nyugati müveltségü, talán onnan is származó férfiúnak gondolta (Kumorovitz 1964.77.)

24 A monostortemplom újra feltárásáról: Molnár 2015., a monostortemplommal kapcsolatos korábbi irodalomról: Molnár 2014. 187189. Azóta a kérdéssel röviden foglalkozott: Takács 2014. 312., Szakács 2015. 176-177. Buzás Gergely már a feltárás eredményeit is figyelembe véve irt az épületről (Tóth-Buzás 2016. 67-69.), majd 2018-ban elkészítette az épület részletes rekonstrukcióját, a kőanyagot is alaposan vizsgálva. A templom legjobb párhuzamait Dalmácia korabeli építészetében találta meg. A példák alapján a nyugati karzat fölé inkább egy tornyot, mint toronypárt tart lehetségesnek. (Buzás 2018.) 


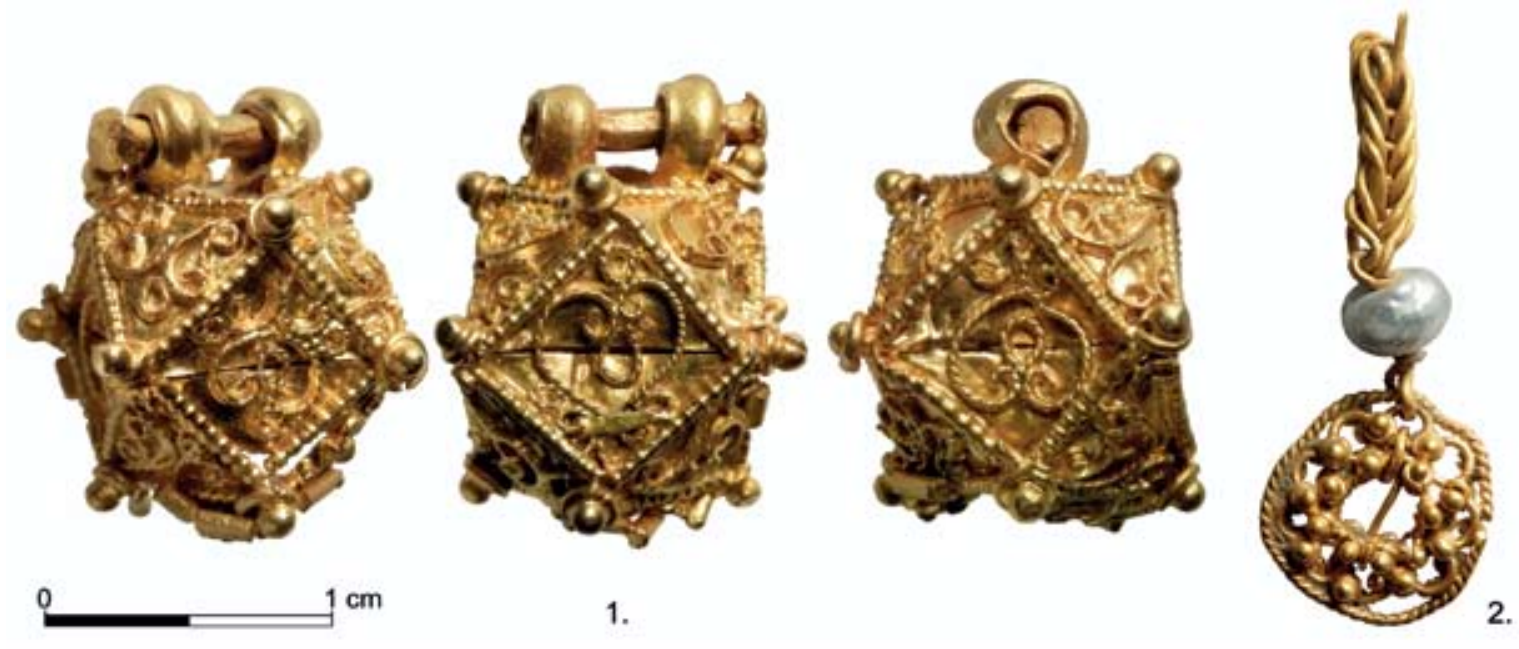

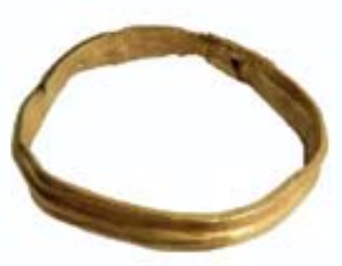

3.

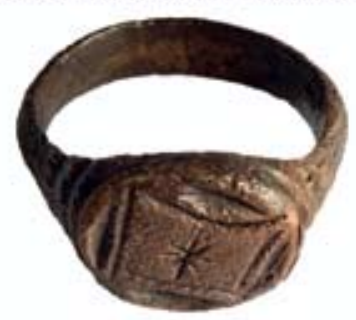

4.

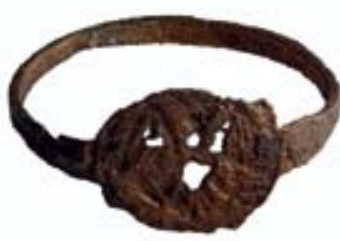

5.

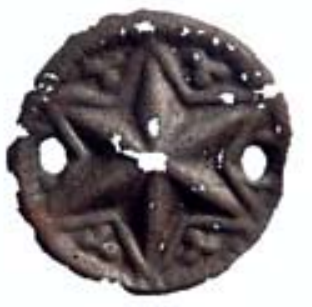

6.

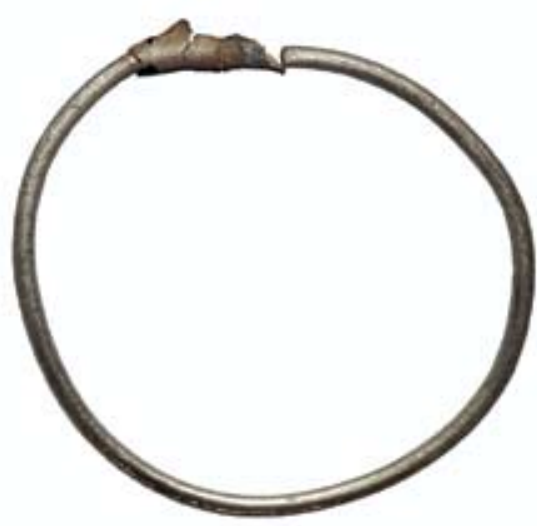

7.
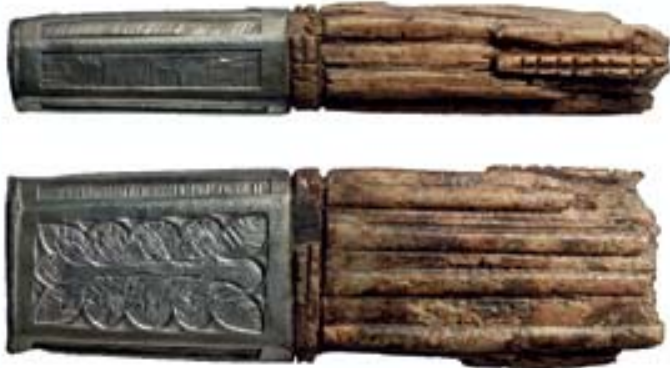

10.

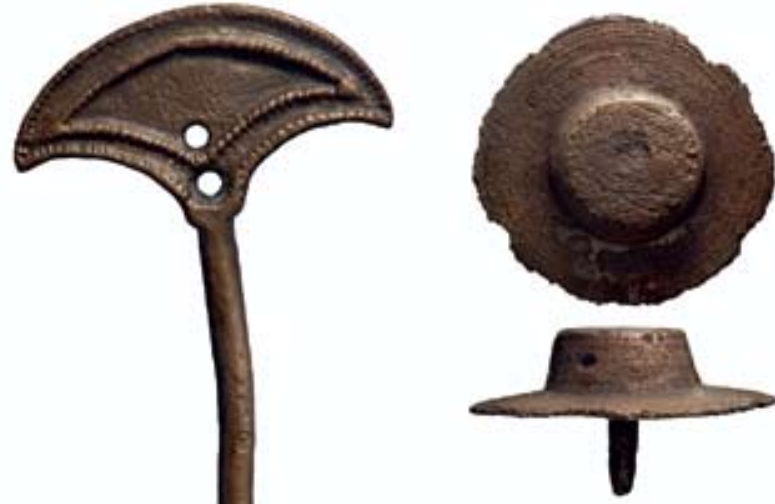

9.

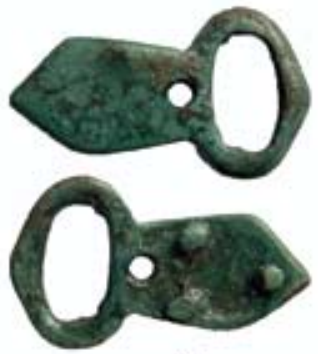

11.

8.

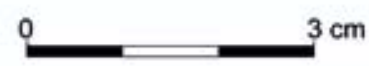

12. ábra. A feltáráson talált leletek: 1.: fémkeresővel talált aranytárgy, 2-3. ill. 11.: a korai sánc padkájának feltöltődésében talált aranytárgyak és bronzcsat. 4-5.: középkori gyürük, 6.: pártaveret, 7.: köpüs záródású karika, 8.: késő bronzkori bronztü, 9.: könyvveret, 10.: ezüstveretes csontnyél 
A 60-as évekbeli feltárások nyomán kirajzolódó kolostornégyzet épületeit Nagy Emese a 14-15. század fordulójára keltezte, az átépítés előtti kolostorról annyit közölt, hogy alaprajza eltér a megszokott kolostorsémától ${ }^{25}$ illetve, hogy egy kisebb, a templomtól elkülönülö épület volt. ${ }^{26}$ Bár még most is erősen hiányosak ismereteink, a korábbi helyiségek nyomát több helyen - a déli szárnyban, a keleti és nyugati kolostorszárny északi részein - is megtaláltuk (13. ábra).

Fontos hangsúlyozni, hogy a monostor környezete ekkor máshogy festett, a mai nagyjából egyenes dombtető a gótikus kolostornégyzet kiépítésekor alakulhatott ki. A monostor életének korai szakaszában még a templomtól délre lejtő dombtetővel és keleten is meredek domboldallal számolhatunk. Az egykori sánc padkái feltöltődtek, de a mai parkoló területén lévő mélyedés (árok) még a mainál mélyebb lehetett. A déli domboldalon több Árpád-kori gödör, cölöplyuk maradványát találtuk meg, amelyek közül több az egykori sánc padkájának feltöltésébe lett ásva.

A későbbi nyugati kolostorszárny északi részén már a gótikus kolostor megépülése előtt is állt egy tekintélyesebb, valószínüleg kéthelyiséges épület. A templom délnyugati tornyához illesztették, alapozása nagyjából 1 méter vastagon ledöngölt rétegekböl és felettük 3 sor sárga agyagos-löszös rétegbe tett téglából áll. Viszonylag jól rekonstruálható a nagyjából $12 \times 5,5-6$ méteres belterü északi helyisége. Az egykori északi és keleti falának szakaszai maradtak meg magasabban. A déli falának (a nyugati kolostorszárny későbbi osztófalának) csak kis induló csonkja van meg, ma már jórészt modern visszaépítés, de a 60 -as évek feltárási fotói alapján ez is a korai helyiséggel együtt épült. A helyiség nyugati falát ma már a kolostor mélyen alapozott, masszívabb, támpilléres nyugati zárófala alkotja. Az eredeti fal talán ettől kissé nyugatra álhatott, mivel a 60-as évek dokumentációjának fotóin látszik itt egy falszakasz. Az épület koráról nehéz biztosat mondani. Sajnos a belsejét csak kis kutatószelvényekkel tudtuk kutatni, a nyugati kerengőfolyosó felöli oldalán hosszabb szakaszon betontuskók akadályozzák a feltárást, de a fennmaradó területen alapozása nem metszett semmit. A templomhoz épült, annál későbbi, de korábbi a kolostornégyzetnél, a kerengő is hozzá igazodott. Sajnos nem tudjuk a közepén lévő nagy pillér építése és a keleti fal déli részén lévő bejáratának nyitása melyik periódushoz köthető.

Az ettől délre lévő terület (a későbbi nyugati kolostorszárny déli része) nagyon hiányosan maradt meg. Mi csak kevéssé kutattuk, a 60-as évek dokumentációja is csak néhány, nem is teljesen egy vonalban álló falszakaszról tudósít, a műemléki helyreállítás pedig jórészt kiegészítés-rekonstrukció. A korabeli dokumentációban a keleti fal északi részét az északi helyiség keleti falának folytatásának jelezték. Sajnos itt is jórészt modern visszaépítést találtunk, csak egy kisebb, kb. $30 \mathrm{~cm}$-es

25 Nagy Emese 1973. 338. Egy kerítőfalról is írt, amire ráépültek volna a későbbi épületek, de ennek egyértelmű nyomát nem találtuk.

26 Nagy 1978. 91., úgy vélem a déli kolostorszárnyba foglalt korábbi épületre gondolhatott, aminek kapcsán az ásatási naplójában is régebbi falakat említett.

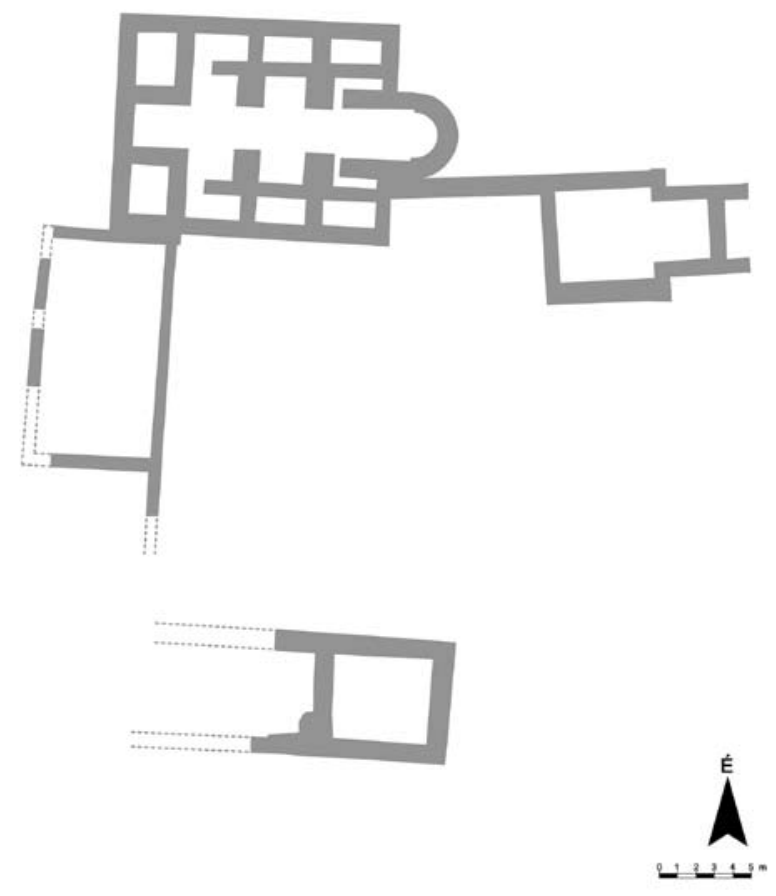

13. ábra. A kolostornégyzet kiépítése elötti épületek azonosított maradványai

falcsonk tanúskodik arról, hogy eredetileg az északival együtt épülhetett a déli helyiség illetve annak északi része. Ebben az esetben már a korábbi időszakban is egy kéthelyiséges épülettel számolhatunk.

A déli helyiség pontos méretét a falak erős pusztulása miatt nem tudjuk megadni, ha nagyjából a később épült falszakaszig ért kb. 6×4-5 méteres lehetett. Az északi részén 1962-ben egy tüzelöberendezést tártak fel, ami alapján a helyiséget konyhának rekonstruálták. Ugyanakkor a kemence egyértelműen a padló alatt volt. Nagy Emese ásatási naplójában kétszintes és két korszakú kemencéről írt, szerinte egy korábbi kemence tűzterének feltöltése után építettek ki a padló szintjén egy újabb kemencét. Úgy vélem valójában egy téglabordás hypocaustum maradványait tárták fel. Mivel az objektumra csak egy kis részen ástunk rá, rekonstruálásához a 60-as évek dokumentációját használhatjuk (14-15. ábra). A tüzelöberendezés $270 \times 220 \mathrm{~cm}$ nagyságú, kissé trapéz alakú volt. A szájánál még megvolt egy téglából épült kb. $80 \mathrm{~cm}$ magas boltíves borda, az egyik régi képen a második bordájának maradványa is felfedezhető. A szája előtt két nagyjából méter hosszan megmaradt falszakasz volt, amelyek egy kemence felé szükülő tüzelőtér maradványai. Ezeket és a boltívet gondosan megépítették, a kemence lefelé kissé lejtős falai viszont habarccsal leöntött bedobált tégla- és kődarabokból álltak. Ez alapján először alapárkot ástak, ebben építették meg a kemence falát, majd elkészítése után ástak le falai mellett és alakították ki száját, bordáit. Nagy Emese naplója alapján a tüzelöberendezés belsejében égett téglákat (nyilván a bordák maradványait) és apró tört 


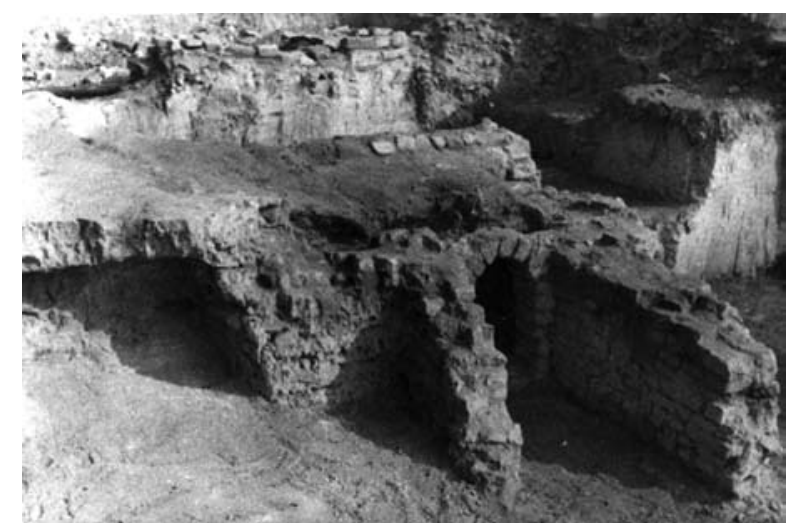

14. ábra. A nyugati szárny déli helyiségében 1962-ben talált hypocaustum (Nagy Emese dokumentációjából)

15. ábra. A hypocaustum rajza (Nagy Emese dokumentációjából)

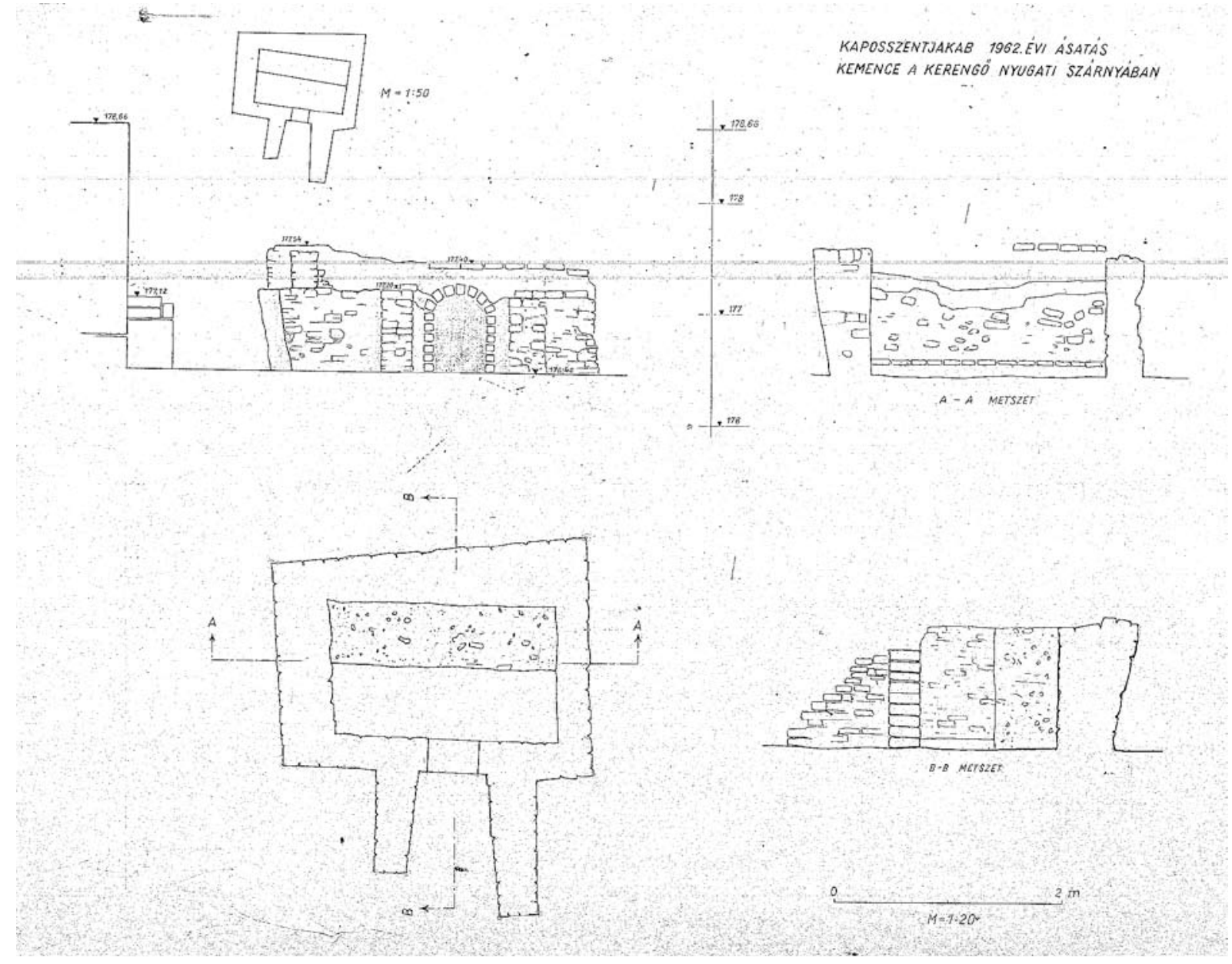

köveket (a boltozás feletti hőtartó rétegének maradványát) találtak. Délröl tüzelték, a terület erős bolygatottsága miatt sem tudjuk a füstje hogyan távozott. Ha egy kisméretű helyiséghez tartozott, akár ezen kívülről is füthették, ellenkező esetben a füstelvezetését kellett valahogy (keresztirányú fallal vagy a tüzelőtér oldalfalaira épített kéménnyel) megoldani. A helyiség északkeleti sarkában megmaradt rövid alapfal-szakasz felső része vörösre volt égve, amely akár a hypocaustum müködésével is összefügghet. A tüzelöberendezés korát pontosan nem ismerjük, nem feltétlenül egyszerre épült a helyiséggel. ${ }^{27} \mathrm{~A}$ hypocaustumok használata inkább a 13-14. századra jellemző, de a 15. században is előfordulnak. ${ }^{28} \mathrm{~A}$ mi példányunkra leginkább hasonló tüzelőberendezések Egerből ${ }^{29}$ és Pécsváradról ${ }^{30}$ ismertek. A hypocaustum miatt a helyiséget feltehetően calefactoriumnakés/vagy fütött refektoriumnak rekonstruálhatjuk. H. Gyürki Katalin szerint a Budai domonkos KEMENCE A KERENGO NYUGATI SZARNYABAN

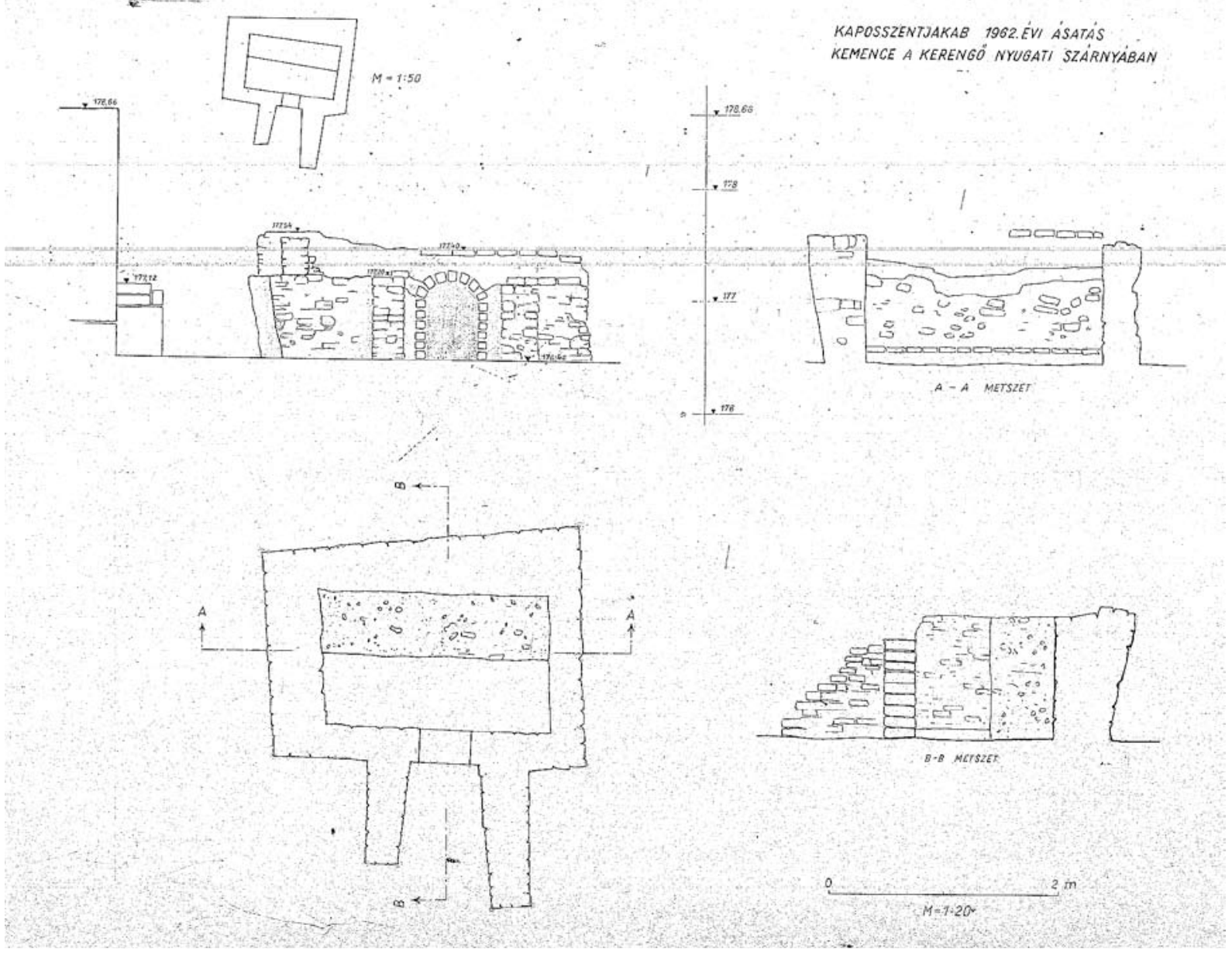

27 Elvileg akár a 14/15. századi kolostornégyzet kiépítéséhez is kapcsolhatnánk, de a mellette lévő korábbi falszakasz alapján inkább annál korábbi lehet

28 Bodó 2010. 374.

29 Kozák 1981. 133-137, Kozák 1990. 364-366. Kozák Károly 14. századi datálását Bodó Balázs nem tarja meggyőzőnek, a tüzelőberendezést 1470-es években épülö palotához köti (Bodó 2010. 374.)

30 Kozák 1981.137-139., Bodó 2010. 374. A tüzelőberendezést Kozák Károly 14. századra datálta, Bodó Balázs 14-15. századon belül nem tartja pontosabban keltezhetőnek. 


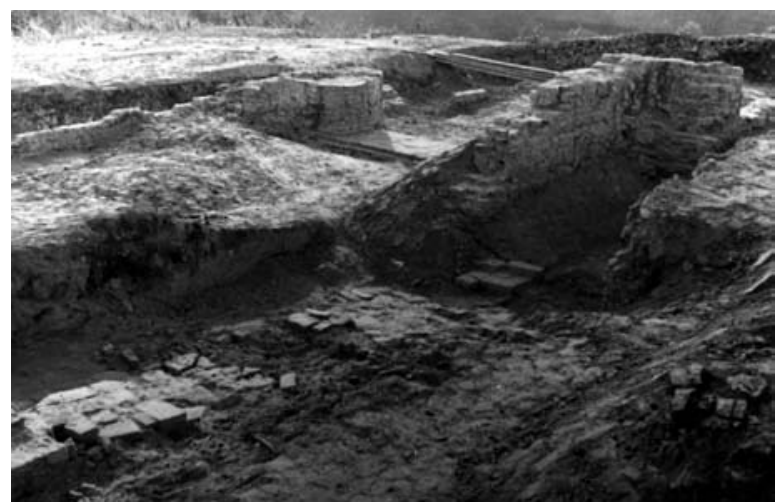

16. ábra. A déli szárnyba foglalt korai helyiség északi fala, háttérben a kolostornégyzet kiépitésekor hozzáépített falak (Nagy Emese dokumentációjából)

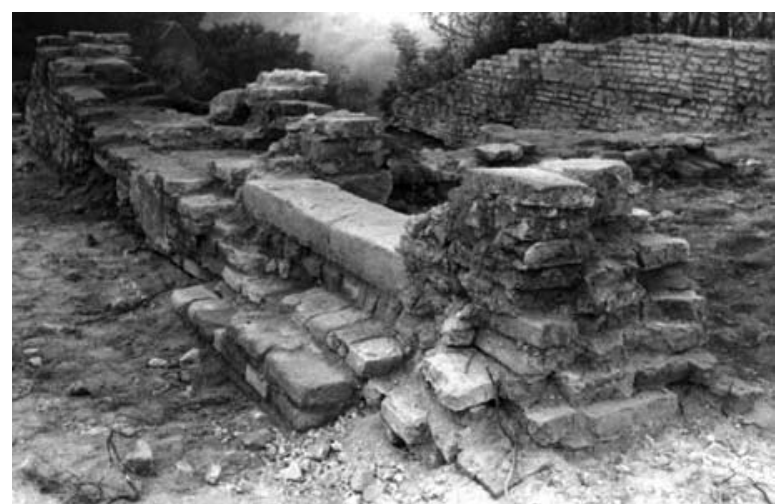

18. ábra. A nyugati szárny északi helyiségének bejárata (Nagy Emese dokumentációjából)

apácakolostor hpocaustumát a calefactorium fütése mellett kenyérsütésre is használták. ${ }^{31}$ Esetünkben is gondolhatunk az egyetlen fütött helyiség többcélú használatára.

A déli szárnyban egy legalább kéthelyiséges korábbi épület maradványait találtunk meg. A legalább $6,5 \times 9,5$ m-es épület padlószintje a későbbi kolostorénál mélyebben volt, még a domb természetes lejtéséhez igazodott. Nagyjából méter széles alapozása téglasorokból és közéjük döngölt sárga löszös rétegekből állt. Északi és déli alapfalának szakaszai a későbbi ráépítések és müemléki helyreállítás alatt figyelhetőek meg (16. ábra), keleti falának az alsó 1-2 téglasorából maradt meg valamennyi. A két helyiség közötti osztófaIon a felmenő fal részlete is azonosítható még, a 60-as évek fotóján belső vakolásának nyoma is látszott. A két helyiség között átjárót nyitottak, amely déli oldalán egy négyzetes alapról induló, nyolcszög három oldalával záródó falpillér alsó része is megmaradt. (17. ábra)

A keleti helyiség nagyjából $6 \times 6,5$ méteres volt, a nyugati helyiség pontos méretét nem tudjuk, mert csak rövid ideig volt módunk követni (ezt északnyugaton a modern lépcső is akadályozza). A déli szárny nyugati

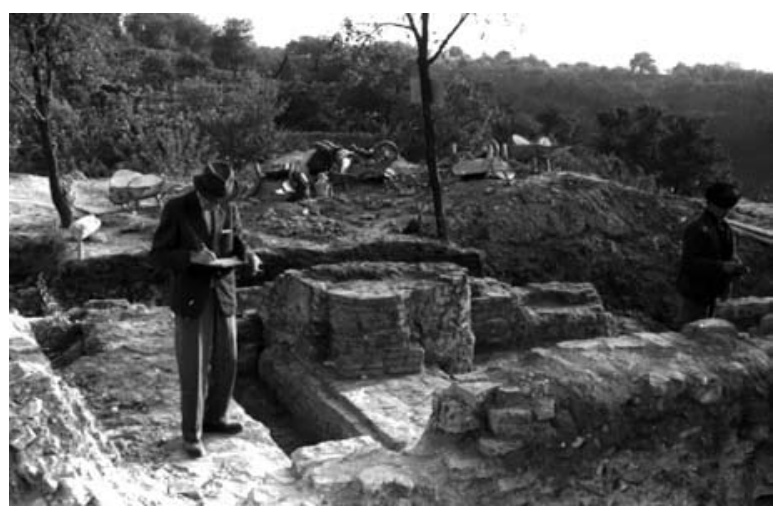

17. ábra. A déli szárnyban lévő korábbi kéthelyiséges épület osztófala

(Nagy Emese dokumentációjából)

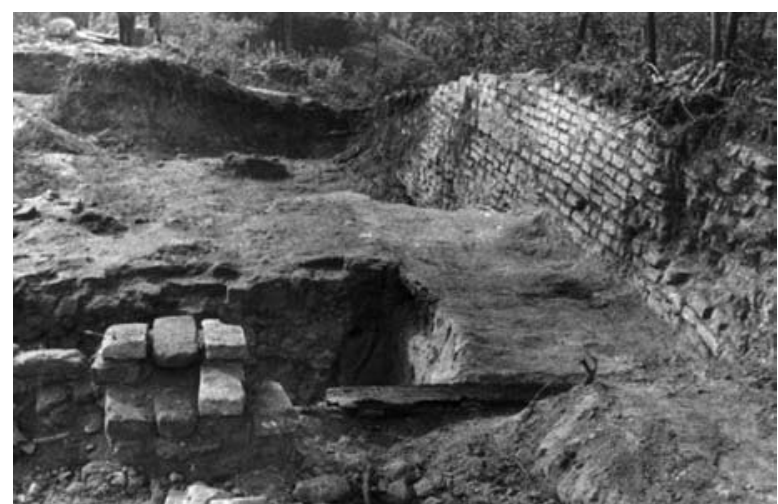

19. ábra. A nyugati szárny két helyiség közötti osztófalon lévő átjáró nyoma. Háttérben a hypocaustum hátsó fala, jobbra a kolostor nyugati fala látható.

(Nagy Emese dokumentációjából)

része teljesen megsemmisült, mindössze 1-2 kis falszakasz maradt meg, amit ma látunk jórészt müemléki rekonstrukció. Északi falának nyugati részén, kis szakaszon hasonló szerkezetü alap alját találtuk meg. Amenynyire a korabeli felszín rekonstruálható, az épület északi fala részben a dombnak támaszkodhatott, viszonylag sekély alapozása alapján is kissé a földe süllyedhetett. Bejáratának pontos helyét nem ismerjük. A faltól délre két helyen is szorosan egymás mellé tett, szárazon rakott téglák, talán külső járószint nyoma volt megfigyelhető. Egyik helyen nagyobb mennyiségü kiömlött habarcs fedi, így biztos nem a későbbi építési korszak terméke, inkább a korai épület időszakához tartozhat. A domb folyamatos megcsúszása matt a délkeleti sarkot erősen toldozták-foltozták, nehezen értelmezhető, de úgy tünik már az eredeti épület is átépítésen esett át.

Az épületet később a kiépülő gótikus kolostornégyzetbe építették be. A pontos korát nem ismerjük, rétegei a természetes pusztulás és a 60 -as évek feltárásai során megsemmisültek. Az általunk kutatott részen csak egy leletanyag nélküli gödröt metsz, de a belsejében Árpád-kori gödrök alját találtuk meg, ami alapján biztos nem a legkorábbi időszak terméke, ugyanakkor korábbi a kolostornégyzet kiépítésénél. 


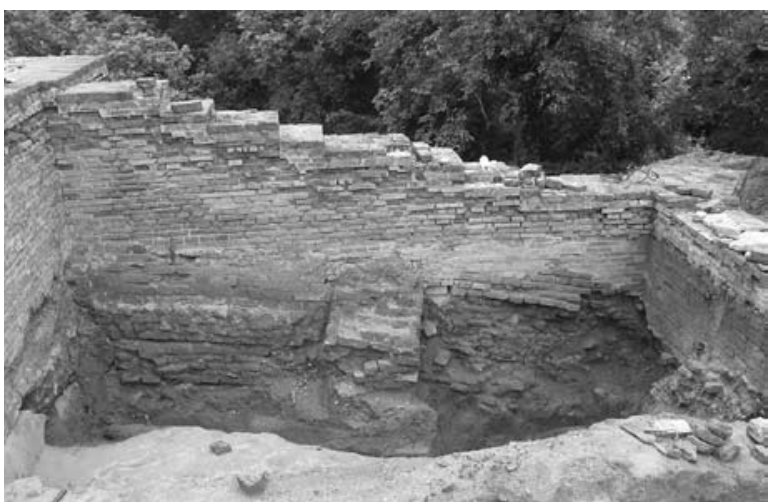

20. ábra. A kolostor déli szárnyának keleti fala. Az újkori visszaépités alatt jól láthatóak megcsúszott fal maradványai

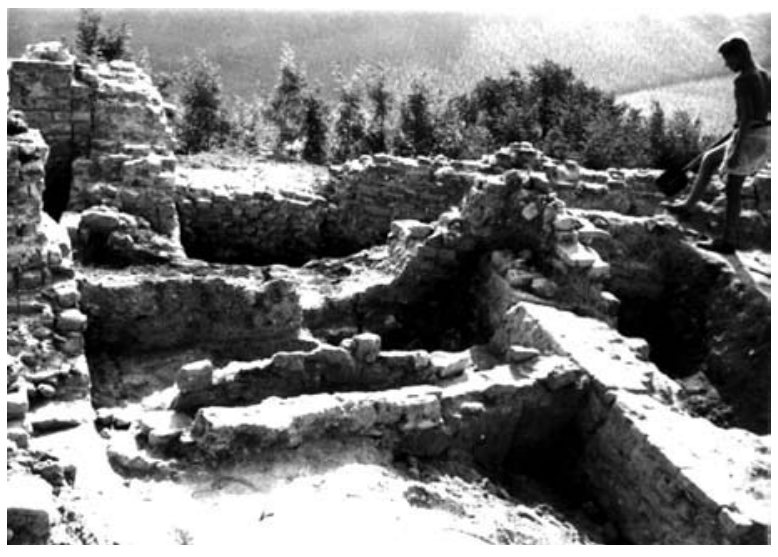

22. ábra. A 60-as években feltárt csatorna (Nagy Emese dokumentációjából)

A templomtól délkeletre a domboldalban egy kőfal maradványait tártuk fel. A falat a későbbi kolostori épületek rombolták, de így is megmaradt két nagyobb szakasza. A domboldalon mélyebben (a dombtetőtöl 6-7 méterrel lentebb) ásott szakaszát támpillérekkel is erősítették. Mivel nincsenek kötésben, feltehetően később épültek a falhoz, felmenő részük alja követte a domboldal egykori vonalát. A falszakaszt később viszszabontották, így felmenő részéből csak kevés maradt, de ezen is látszik, hogy a hozzáépített támpillérek ellenére kiborult. (10. ábra) Délebbre a fal egy másik darabja őrződött meg, amely kissé „bekanyarodik” a domb magasabb része felé, majd megszakad. A domboldal későbbi feltöltése miatt itt a felmenő falból is nagyobb részlet megőrződött, így jól megállapítható, hogy a meredek domboldalra épült, a kidolgozatlanabb belső oldala a dombnak támaszkodott. A dombtetőn nem találtuk folytatását, de Nagy Emese ásatási rajza és fotói alapján északra folytatódott, ráadásul a 60-as években a templomtól nyugatra, délnyugatra is egy hasonló fal szakaszát tárták fel a domb oldalában. ${ }^{32}$

32 Nagy Emese dokumentációjának fotója és rajza közölve: Molnár 2014. 191-192. 9. és 11. ábra

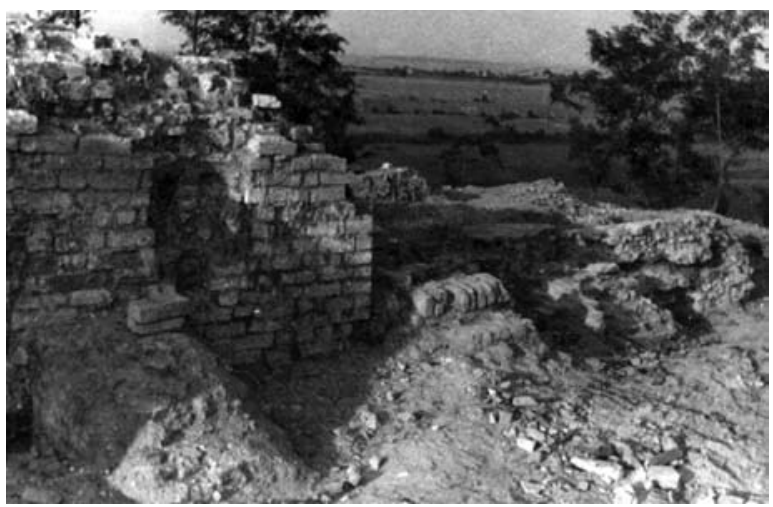

21. ábra. A templomtól keletre lévő terület. (Nagy Emese dokumentációjából)

A falszakaszok feltehetően támfalként szolgálhattak. Mivel az amúgy is meredek domboldal jó részét a korábbi sáncok padkáinak laza feltöltése foglalta el, az évszázadok során több alkalommal is megcsúszott a domb földje. A jelenségre már Nagy Emese is felfigyelt, ${ }^{33} a$ feltárás során mi is több helyen kiborult, megcsúszott falszakaszokat találtunk (20. kép). Úgy tűnik, már viszonylag korán érzékelték a domboldal instabilitását, ezért a templom körüli területet támfallal erősítették. Mint már utaltam rá, ez sem oldotta meg a problémát, a fal maradványait félig kiborulva találtuk meg. Ezután nagyrészt visszabontották, majd részben maradványaira, támpilléréire alapozva egy félig domboldalba ásott téglaépület készült, amelyet kápolnaként azonosíthatunk. Liturgikus funkciója mellett valószínűleg a megcsúszó domboldalt is igyekeztek (úgy tünik sikerrel) megfogni. A viszonylag magas falakkal megmaradt, egykor boltozott, 8,3 hosszú belterü épület egy közel $5 \times 5$ m-es belterü hajóból és egy $3,3 \times 3,3$ belterü szentélyből állt. A szélesebb déli falában futott egy részben megmaradt és helyreállított lépcső, aminek végén, az egyenes záródású szentély előtt tudtak a kápolnába lépni. (11. ábra) Az épületrészt Nagy Emese pinceként említette, de ennek már az is ellentmond, hogy a keleti oldalának felmenő falmaradványai alapján nem volt külső bejárata, csak a lépcsőn lemenve volt megközelíthető. $A$ helyiség déli, több méter mélyen dombba ásott falainak alapozásakor felül szélesebb, lefelé keskenyedő árkot ástak, amely visszatöltését egy vékony sávban még sikerült megtalálnunk. A benne lévő kerámia alapján a 13. század második felénél korábban nem készülhetett a kápolna, ugyanakkor a 14/15. század fordulójára keltezett kolostornégyzet keleti szárnyának falai hozzá épültek, így az épületet a 13. második felére vagy a 14. századra datálhatjuk. A feltételezhető magassága alapján akár egy emeleti helyiség (káptalanterem?) is lehetett volna rajta, de az épület nagyfokú pusztulása miatt a kérdés már nem eldönthető. A kápolnától délre, a később kiépülő keleti kolostorszárny helyén, a meredek domboldalon ekkor még nem álltak épületek.

33 Nagy 1973. 338. 
A templom délkeleti sarkánál ma is viszonylag magasan álló fal alapozását kutatva 2014-ben megállapítottuk, hogy eredetileg a kápolnáig tartott. Ekkor a falszakaszt egy csatlakozó épület északi falának gondoltam, de déli falának 2016-ban nem találtuk nyomát. Könnyen lehet, hogy azt a kerengő kiépítésekor és a kései sírokkal vagy az újkori építkezésekkel rombolták, eltüntették maradványait, sajnos a terület már a 60-as évekre erősen rombolva volt, a később beépített betontuskók is akadályozták újrafeltárását. ${ }^{34} \mathrm{Az}$ alapfal Árpád-kori sírokat rombol, de a kolostornégyzet kiépítésénél egyértelműen korábbi. A falnál jóval szélesebb alapozást késői sírok rombolták.

A kolostorudvaron és a kerengőfolyosókban nem találtuk korábbi falak nyomait, úgy tűnik a késő Árpádkori kolostor épületei már egy kissé szabálytalan, trapéz alakú udvar köré szerveződtek. Az épületek nem egyszerre épületek, pontos funkciójukat sem tudjuk teljesen meghatározni, feltehetőn a déli épület lehetett a korai kolostorépület, a nyugati kéthelyiséges épület refektorium, calefactórium, konyha számára készülhetett, a keleti szárnyban lévő kápolna elkészülte már nem sokkal előzhette meg a kolostornégyzet kiépülését.

Több hasonló korú bencés monostornál megfigyelhető volt, a korai időszakban általában nem épült meg szabályos kolostornégyzet (a szegényebb vagyonú monostorok jó részében később sem). Ugyanakkor a felépítet épületek elhelyezkedése sokszor valamilyen szabályosságot mutat, tengelyük a temploméra nagyjából meröleges vagy párhuzamos volt, udvar köré épültek, a későbbi szárnyakba befoglalhatók voltak. ${ }^{35}$

$A z$ épületek által bezárt területről keveset tudunk, nem tudjuk pl. volt-e itt kút a korai időszakban. A terület délkeleti részén figyelhettünk meg Árpád-kori objektumokat. A déli kerengőfolyosót az udvartól elválasztó fal alapozása alatt, attól csak kissé eltérő tájolással egy sorban négy nagy cölöphely nyomát találtuk. A keleti három hasonló: oválisak, nagyméretűek, eredetileg mélyek voltak, de az alapozás alatt sekélyebben maradtak meg. Az egyikben több Árpád-kori kerámiát találtunk. ${ }^{36}$ Vastag gerendák állhattak bennük, lehetnek valamilyen kerítés vagy korai faépület nyomai is.

A monostortemplomtól kb. 20 méterre északra lévő nyolcszögletes alaprajzú, a nyolcszög öt oldalával záródó szentélyű plébániatemplomot formája alapján Nagy Emese a 13. század végére, esetleg a 14.

34 A fal a templom és a kápolna között egyfajta kerítőfalként is funkcionálhatott, esetleg a helyiség északra lehetet, egy nagyon hasonló szerkezetű fal indul a templom északkelti sarkától is. Sajnos az a terület még jórészt újra feltárásra vár.

35 Ellésmonostornál egy templom szentélyéhez délről csatlakozó, és egy templommal párhuzamos déli épület került feltárásra (Pávai 2000), Pásztón egy keleti és egy nyugati szárny épült ki (Valter 1982. 194-195.). A kánai (H. Gyürki 1996. 99-102.) és vésztői (Juhász 2000) monostorban is a keleti szárnyban volt a korai kolostorépület, a szabályos kolostor csak később épült meg. A visegrádi Szent András monostort a bazilita szerzetesektöl a 13. században átvevő bencések először a nyugati szárnyban építettek egy téglalap alakú köházat, míg a kolostornégyzet csak a következő században készült el. (Buzás - Mészáros 2008. 75-76.)

36 A legnyugatabbi objektum még nagyobb és mélyebb, de ebben öskori kerámia volt. század elejére keltezte. ${ }^{37}$ Érdemes megemlíteni, hogy a 60-as évek feltárási fotóin valamilyen korábbi épület nyomai látszanak a plébániatemplom alatt, ahogy egyelöre értelmezhetetlen, általunk még nem kutatott falszakaszok vannak a monostortemplomtól északkeletre is.

Valamikor ebben az időszakban kezdhették meg egy végül el nem készülő, hasonló poligonális szentély építését a monostortemplomhoz. ${ }^{38}$

\section{A kolostornégyzet kiépítésének időszaka}

A kolostor négyzetes udvara a kerengőfolyosóval és a hozzá csatlakozó épületekkel Nagy Emese véleménye szerint a 14-15. század fordulóján épült ki. Datálása a kerengő kőfaragványainak stílusán alapult, az építkezést a monostor életében ekkor meglévő nyugodt időszakkal magyarázta. ${ }^{39}$ Többen felhívták a figyelmet az 1392-es pápai búcsúengedélyre, mint amely az építkezéshez is kapcsolódhatott. ${ }^{40}$

A keltezésnek az új feltárások eredményei sem mondanak ellent. A kolostortól délre és keletre több helyen találtunk egy vékony faszénsávot, e felett pedig egy 20-60 cm vastag sárgás, löszös réteget, amelyek már Árpád-kori beásásokat, gödröket rétegeznek felül, de a kolostornégyzet alapfalai által metszve vannak. A faszenes réteg valamilyen tűzvész nyoma, a dombtetöről letermelődött, kissé kevert sárga réteg a tűzesett miatt is szükségessé váló építkezések előtti elegyengetésének nyoma lehet. A sárgás rétegben általunk talált csekély kerámiaanyag alapján biztosnak tünik, hogy a 14. századnál korábban nem épülhetett meg a kolostornégyzet, amelynek szabálytalanságait a domb alakjához és a korábbi épületekhez való igazodással magyarázhatjuk. Nagy Emese naplójából értesülünk arról, hogy a 60-as években egy gödröt tártak fel a déli kolostorszárny keleti végénél, a korábbi épületen kívül. A gödör betöltésében 14. századi kerámiát találtak, ami szintén alátámasztja az ennél későbbi épület 14. századi vagy későbbi keltezését.

A templom átépítése a boltozat kőfaragványainak hasonlósága alapján a kerengő kiépítésével egyszerre történhetett. Legkésőbb ekkorra a középső pilléreket, így a hozzájuk kapcsolható tornyot is elbontották, a hajó padlójának szintjét lesüllyesztették, a szentélyét megemelték, egy szentélylépcsőt alakítottak ki. A szentély előtt ma is látható oszloplábazatokat ekkor elfalazták - ennek köszönhetjük megmaradásukat. ${ }^{41}$ Buzás Gergely a templom keresztboltozatának hornyolt ékbordái alapján a 14. századra, a 15. század elejére keltezi az átépítést. ${ }^{42}$

37 Nagy 1973. 338. Az épület plébániatemplomként való azonosításában egy 1529-es forrásra is támaszkodott.

38 Molnár 2015. 192. Az építkezést a templom átépítéséhez és a kolostor kiépítéséhez is kapcsolhatnánk, de az egyedi alapozása és az arra épített (a kolostornégyzettel valószínüleg egykorú) falak alapján valamivel korábbra helyezném.

39 Nagy 1973. 338.

40 Először a helyreállítást vezető Zádor Mihály írt erről, ugyanakkor egy későbbi, 15. század közepi-végi építési periódust is feltételezett. (Zádor 1964. 47. és 51-52.)

41 Molnár 2015. 191-192.

42 Buzás 2018. 3. 


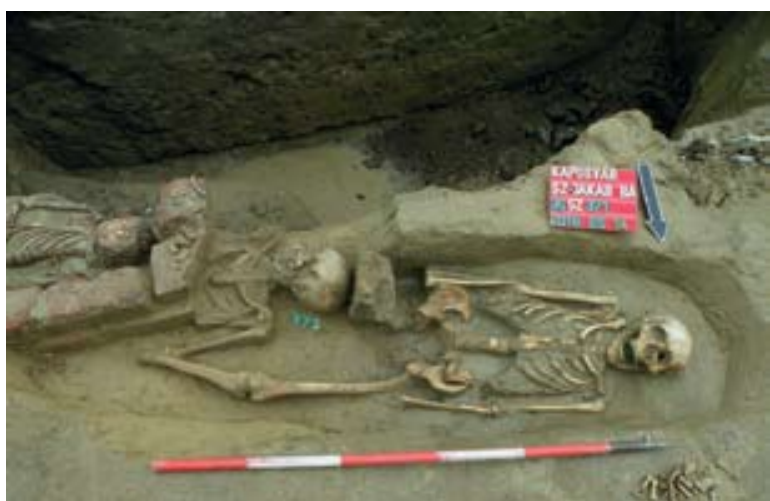

23. ábra. A késői időszakban ásott kút által rombolt, egymást többszörösen metsző sírok

Több jel is arra utal, hogy a kolostornégyzet több lépcsőben épült ki. A keleti szárny alsó szintjén, a domb aljában nem volt helyiség, csak a viszonylag szabályos kolostornégyzet kiépítéséhez töltötték fel a dombot. A most is viszonylag magasan meglévő, keleti, támpillérekkel is megtámasztott falat a ferde domboldalba építették, majd a falak közé földet hordva a kerengő szintjével egy magasságra hozták a területet. A keleti és nyugati fal is hozzáépült a kápolna déli falához. A feltárás során az egykori ferde domboldal vonalát őrző sárga altalajt és a korai padkák feltöltődött maradványait találtuk meg, semmi jele nem volt középkori helyiségnek. Az épület nyugati falának viszonylag sekély indulása is arra utal, hogy ilyet csak a feltöltés tetején, a kerengővel egy szinten, esetleg attól kissé mélyebb járószinttel alakíthattak ki. A fal alsó 80-120 cm-en földbe tett téglából áll, ami biztosan az alapozás része, a felette habarcsba falazott téglákból álló rész indulása is csak 1 méter mélyen van a kerengő szintjétöl. A 60-as években feltártak a keleti zárófalnak belülröl támaszkodó, a feltöltésen álló kisebb falszakaszokat is. Ugyanekkor a nagy „helyiség” déli részén, a feltöltés tetején 1-2 cm vastag sávban égett növényi maradványokat (jórészt búzát és babot) találtak. ${ }^{43}$ Helyzetük arra utal, hogy a kerengő szintjén álló építményt (legalább a kései időszakban) élelmiszer tárolására használhatták.

Nyugaton a dombtető szélére mélyen alapozott téglafalat építettek, amit szintén masszív nagy támpillérekkel erősítettek. A templom déli tornyához korábban épült kéthelyiséges épületet befoglalták a nyugati szárnyba. Ekkor már biztos elkészült az északi helyiség közepén lévő nagy négyszögletes pillér, amely alapozása is habarcsba falazott téglákból áll. Az erősen megépített pillér a tetőt is tarthatta, de hasonlókat kolostori konyhák kéménykürtőjéhez is kapcsolnak. ${ }^{44} A$ helyiség bejárata ekkor már biztos a keleti fal déli részén volt. Bár csak kis területen kutattuk, megtaláltuk a padlóját is, amit fél téglákból, nagyobb tégladarabokból szárazon rakták. A korábbi időszakhoz képest lesüllyeszthették, a kerengő padlójával kb. egy szinten volt, a 60-as években még

43 A talált növényi maradványokról: P. Hartyáni - Nováki 1975. 37. 44 Orosz 2010. 583., Mezősiné Kovács 1994. 316.

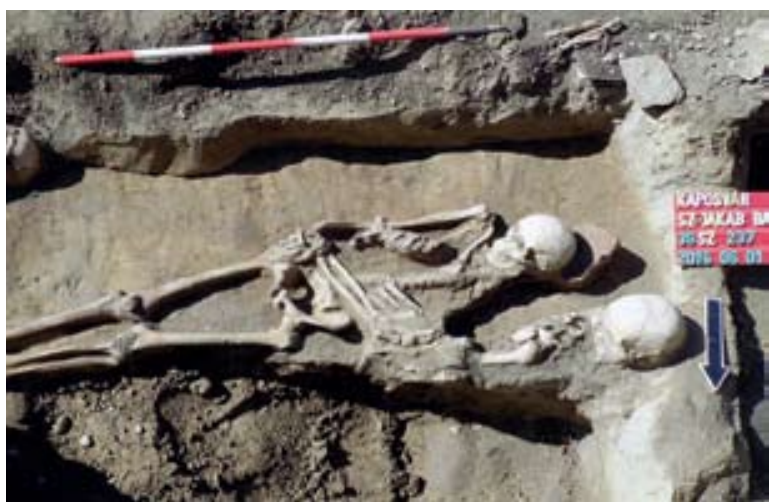

24. ábra. A kolostorudvaron feltárt temetkezés. Az elhunyt feje alá téglát tettek, mellé egy rombolt korábbi sír csontjait helyezték

a kerengőbe vezető lépcső is megvolt (18. ábra). A délre lévő helyiséget erősen átalakították. A kettő közötti falon, a nyugati szárny osztófalán a 60-as években még egy elszenesedett gerenda jelezte az átjáró helyét (19. ábra).

Mint utaltam rá a délnyugati helyiség déli és keleti falai hiányosan maradtak meg, most jórészt műemléki helyreállítást láthatunk. Nagy Emese dokumentációjában is jelez egy az északiakkal egyirányú, de nem egyvonalban lévő, azoktól kissé nyugatra elcsúszó falszakaszt. Ezt megkeresve egy habarcsba falazott téglából készült alapfal maradványát találtuk meg. Feltehetően a korábbi helyiséget növelték meg egy kb. 5,5-6×8,2 $\mathrm{m}$ belterü újat kialakítva. Az itt álló hypocaustumot - ha nem is teljes bizonyossággal - inkább a korábbi időszakhoz köthetjük, feltehetően ekkor szüntették be a használatát és töltötték be tüzterét, hiszen az új padló már fedte. ${ }^{45}$ Egy cserépkályhával váltották fel - a nyugati szárny két helyiségének találkozásának környékén, a 60-as években számos kályhacsempe kerül elő.

Délen, a domb lejtőjén álló épületet is befoglalták a déli kolostorszárnyba, a falait újabb falszakaszokkal és támpillérekkel erősítették. Sajnos 2016-ra már nem maradtak középkori rétegek, nem tudjuk, hogy az eredetileg mélyebben lévő padlószintü épületet feltöltötték-e, padlószintjét felhozták-e a kerengő méterrel magasabb szintjéig. A déli szárny nyugati része teljesen megsemmisült, jórészt rekonstrukció látható a területen. Mi csak egy rövid alapfalszakaszt találtunk, amely nem a rekonstruált fal alatt volt. A Nagy Emese dokumentációjában lévő alaprajzon kb. a nyugati kolostorszárny vonalában egy falcsonkot jeleznek. Elképzelhető, hogy a déli kolostorszárny háromhelyiséges volt vagy a helyreállításban megmutatott $\mathrm{DNy}$-i sarokig nem is ért ki. A korábbi helyiség keleti falát elbontották és az épületet kelet felé meghosszabbították. A délkeleti sarka a korai sánc feltöltött padkájára épült, a laza föld és a meredek domboldal miatt többször megcsúszott, egy szakasza teljesen hiányzik (20. ábra). A padka feltöltése miatt mélyen alapozták a falakat, de később így is meg kellett erősíteni, ekkor a sarokra egy nagy támpil-

45 Elvileg nem zárhatjuk ki, hogy már a megújított helyiséghez tartozott és rövid müködés után váltották fel a cserépkályhával. 


\section{ÚJABB KUTATÁS A KAPOSSZENTJAKABI APÁTSÁG TERÜLETÉN 2. A 2016-BAN VÉGZETT RÉGÉSZETI FELTÁRÁS}

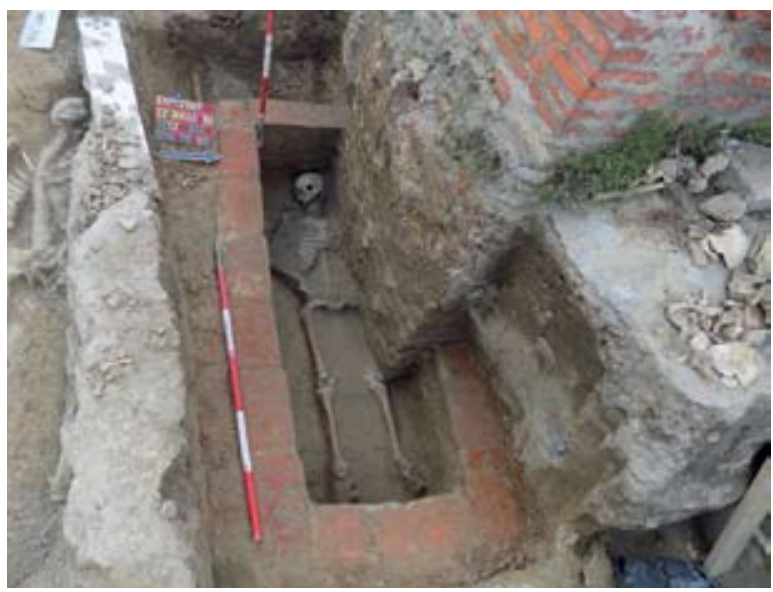

25. ábra. A kerengő fala által rombolt téglakeretes sír

lér épült. A déli kolostorszárny keleti zárófalának és a keleti szárny nagy (a feltöltéshez épült) helyiségének déli falának alapozása egyszerre készült. A derékszöget bezáró falszakaszok kötésben vannak, hasonló szerkezetüek, alul földbe tett, magasabban habarcsba falazott téglasorok alkotják. A falak találkozása „betör” a kerengőbe, amiből arra következtethetünk, hogy az épületekkel körbevett zárt kolostorudvar kiépítése valamivel megelőzhette a kerengőfolyosók (legalábbis a keleti és déli szárny) kialakítását.

A kerengő kiépítése is jól érzékelhetően két szakaszban ment végbe. Az udvar körüli alapfalakon jól megfigyelhető, hogy először az északi szárny készült el. Mivel a boltozat a templomnak támaszkodik annak átépítésével, boltozásával egyszerre épülhetett.

Csak valamivel később épült meg az udvar keleti, nyugati és déli fala, valamint a hozzá csatlakozó kerengőfolyosók. Egy északi oldalán keskenyebb trapéz alakú, 13,8×14,5×15,2×15 m nagyságú udvart alakítottak ki, a habarcsba falazott téglasorokkal alapozott falak belső oldalán támpillérek álltak. Az északi falból viszonylag magas felmenő részek is megmaradtak, a középen lévő bejárata két oldalán egy-egy ablak nyílott. A templom és az udvar északi falán összesen 3 helyen a boltfészkek is megmaradtak. Az udvar körüli kerengőfolyosó 2,8-3 $\mathrm{m}$ széles volt. A padlójának maradványait is megtaláltuk, egy szürkés, elegyengetett rétegre szárazon rakták a nagyméretű egész és fél téglákat. $A$ kerengő kő bordákkal és zárókövekkel felépülő boltozatát az udvar és a környező helyiségek falára terhelték.

Az északi részen a kerengő boltozata a templomnak támaszkodott, a templomtól keletre a folyosó kiszélesedett, a templom délkeleti sarkánál induló korábbi fal alkotta északi falát. A vastag alapra épített fal közepét északi oldalról támpillérrel erősítették. A templom és a fal találkozásánál a 60-as években még jól látszott egy boltozat indulása. ${ }^{46} \mathrm{Ez}$ tartozhatna korábbi helyiséghez is, de valószínübb, hogy a kerengő kiépülésekor készül-

46 Nagy Emese ásatási fotója közölve: Molnár 2015. 192. 10. ábra hetett. Feltételezhető, hogy a kiugró résznél a boltozatot nem egyből a kerengő déli falára, hanem közbülső pillérre terhelték, sajnos a terület szétásása és a lehelyezett betontuskók miatt nehéz az egykori állapotot pontosan rekonstruálni. Az északi fal keleti részén alakították ki a kolostor bejáratát, Nagy Emese egy lépcső maradványát találta rajta. (21. ábra) A templomtól keletre lévő téglalap alakú épület is ekkor készülhetett, de ezt sajnos nem volt módunk kutatni. A kolostorba való bejárásra az építmény és a templom között, a falon kialakított bejáraton, a lépcsőn lemenve volt mód.

Valamikor ekkor készülhetett el a templom szentélyétől északra lévő, általában sekrestyeként azonosított helyiség is. Korábbi falakat is metsz, így a megkezdett, de nem megépülő szentély alapfalára is ráépült.

A kolostor délkeleti sarkában lévő helyiség már a kerengőfolyosók kiépülésekor készülhetett. Kiépítésével a kolostornégyzet teljessé, a déli és keleti kerengöfolyosó kiépíthetővé vált, hiszen az itt futó falakat viszszabonthatták. A helyiség északi falául a nagyméretü keleti építmény déli fala szolgált, ehhez épült a többi. A déli falát alapozási szintjén bekötötték a déli szárny keleti falába. A járószintje magasan lehetett. Belsejét kutatva a domb földjét illetve a korai sánc padkájának feltöltődését, ebbe ásott objektumokat és egy ezeket is fedő feltöltési réteget találtunk. A déli kerengőfolyosó déli falának keleti vége újkori visszaépítés, eredeti falnak nem találtuk nyomát. Az új épület és a déli szárny keleti fala között maradt kis területen akár egy bejáratot is kialakíthattak. Nagy Emese dokumentációjának fényképein ezen a területen téglasorok látszanak, ami talán lépcső nyoma lehet.

A nyugati és keleti zárófalakat, az udvar körüli falakat, a nyugati szárny és a déli szárny hozzáépítéseit sárgás habarcsba rakott téglával alapozták. A keleti kolostorszárny nyugati valamint déli falánál és a déli szárny keleti falánál, a habarcsos falazás alatt olyan téglasorok is voltak, ahol földréteget tettek a téglasorok közé. A korai sáncok feltöltésének lazább földje miatt kellett mélyebben alapozni, jellemzően ott vastagabb ez az alsóbb réteg, ahol a vastagabb a laza feltöltődés.

A déli kerengőfolyosó keleti részén egy csatorna részletét tárták fel a 60-as években (22. ábra). Sajnos 2016-ban még kisebb darabján találtuk meg, mivel a déli részét egy betontuskó rombolta. A déli kolostorszárnyban nincs meg a folytatása, és Nagy Emese dokumentációja alapján, a kolostorudvaron sem volt nyoma. ${ }^{47} \mathrm{Az}$ alja és oldala habarcsba tett téglákból állt, teteje (ha volt is) nem maradt meg. A csatorna nagyjából $60 \mathrm{~cm}$-rel a kerengőfolyosó padlója alatt volt, ÉÉNy-DDK-i irányban futott és DDK-re lejtett, az udvarról vezette le a vizet. A kora nem megállapítható. Mélysége alapján az egykor lejtős domb vonalát követhette, a vizet a korai helyiségtöl keletre vezette volna. A gótikus kolostor már magába foglalta ezt a területet, így csak a kialakított helyiség padlója alatt futhatott volna folytatása. Sajnos a környező rétegek és a müemléki helyreállítás után ma már nehéz értelmezni.

47 A kolostorudvar délkeleti része az oldalán lévő betontuskók és a közepén lévő fa miatt 2016-ban már nem volt kutatható. 


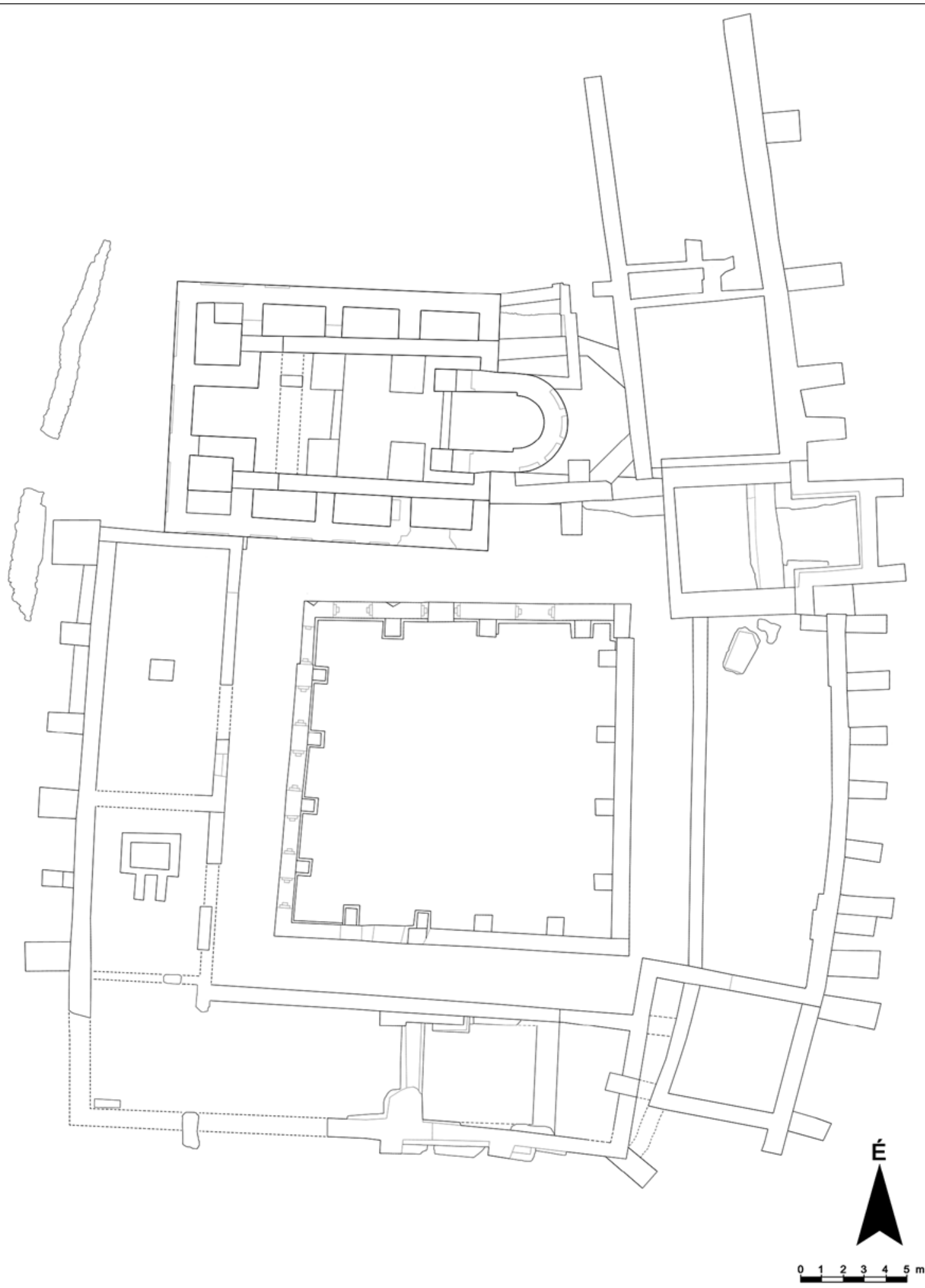

26. ábra. A monostor alaprajza. A Meridián Kft által készített felmérés, Nagy Emese dokumentációjában lévő alaprajzok és a 2014. és 2016. évi feltárások rajzainak felhasználásával készült. A falak egymáshoz való viszonyát csak ott jelöltük, ahol az elmúlt évek feltárásai vagy 60-as évek ásatási dokumentációja alapján ez viszonylag nagy biztonsággal megállapítható volt. Szaggatottal jelöltük azokat a „hiányzó” falszakaszokat, amelyeket a müemléki helyreállitás jelöl vagy maradványaikból jól kiszerkeszthetőek. 
A kolostor helyiségeinek azonosítása nehézségekbe ütközik, valószínü, hogy a nyugati szárnyban volt a konyha és a refektórium. A keleti szárny északi részén, talán a kápolna felett, káptalantermet alakíthattak ki. Ettől délre vagy a déli szárnyban lehetett a szerzetesek hálóhelye. A keleti szárny déli része a késői időszakban, a várra alakítás után élelmiszer tárolására szolgált, de korábbi funkcióját nem ismerjük. A templom szentélyétől északra sekrestyét alakítottak ki, míg a templomtól keletre, a kolostornégyzeten kívül álló helyiség feltehetően apáti ház, vendégház lehetett.

\section{A török-kori végvárrá alakítás}

A kolostor külső falait erősítő támpilléreket időnként a kolostor várrá alakításával szoktak kapcsolatba hozni, de a bizonytalan, folyamatosan megcsúszó domboldal megtartása már magában is indokolta a falak megerősítését, megtámasztását. Nagy Emese említ egy a müemléki helyreállítás során előkerülő, a keleti zárófalon kívüli, feltehetően a várrá alakításhoz kapcsolható falszakaszt. ${ }^{48}$ Sajnos erröl bővebb információnk nincs, az általa közölt alaprajzok nem jelzik, mi nem ástunk az adott területen. Ugyanakkor a kolostor késői időszakához, végvárként való müködéséhez kapcsolható jelenségeket is megfigyelhettünk.

A kolostorudvaron valószínüleg ekkor készült egy nagyméretű objektum, kút vagy ciszterna, amelynek kiásásakor számos sírt romboltak. A legalább 6-7 méter átmérőjü, függőleges falú objektumot 4 méter mélységig bontottuk, a balesetveszély miatt az alját nem érhettük el. A talajvíz nagyon mélyen van, de a korszakból ismertek hasonlóan mély kutak, ${ }^{49}$ esetleg az alján kialakított vízzáró rétegekkel ciszternaként is működhetett. Feltehetően a falakon belüli vízforrásra volt szükség az erődítés kialakításakor. Mivel egymást több rétegben is felülrétegző sírokat rombol, biztos nem a korai időszakból való (23. ábra). Sajnos a monostor korai vízellátásáról nagyon keveset tudunk, akár korábban is állhatott itt kút, de a falakon kívülröl is hozhatták a vizet.

Szintén ebben az időszakban készülhetett egy nagyobb méretű kemence az akkor már nyilván nem rendeltetésszerűen használt kerengőfolyosó ÉNy-i sarkának padlójára. A 60-as években nagyrészt már feltárták, a vázának áglenyomatai és a köré rakott téglasor alsó sorai is megmaradtak. A sütőfelületét megújították, mindkét platnija alatt kerámiaréteg volt.

Úgy tünik a keleti kolostorszárnyban álló boltíves kápolna feltöltésre került, amit szintén a védelmi célok indokolhattak. Ezt alátámasztja az a késői leletanyag is, amit a 60 -as évekbeli feltárás után megmaradt kevés eredeti rétegben találtunk.

Nagy Emese még számos jelét (fegyverek, lószerszámok, tüzelésnyomok, eldobált állatcsontok) érzékelte a katonaság jelenlétének. Esetünkben figyelemre méltó a 16. század közepéről származó pénzek nagy aránya az éremanyagban. (Sajnos a pénzeket jórészt

48 Nagy 1973. 338.

49 A térségben Zrinyiújváron tártak fel nagyon mély kutat (Költő László közlése). 60-as években átforgatott földben, fémkeresővel találtuk.) A kolostorudvar felső rétegeit a 60-as években feltárták, a korabeli dokumentáció képein számos cölöplyuk látszik, amelyek többé-kevésbé sorokba látszanak rendeződni. A síroknál későbbiek, a felettük lévő rétegben voltak, két hasonlót nekünk is sikerült kibontanunk. Talán a katonaság által a kolostorudvarra épített késői, faszerkezetü épületek nyomai lehetnek.

\section{Temetkezések}

A lelőhelyen a temetkezések feltárása már a 60 -as években megkezdődött, majd 2014-ben és 2016-ban is folytatódott. A sírok helyük alapján három csoportba sorolhatóak. A monostortemplomban lévőeket jórészt a kegyúri családhoz köthetjük. Nagyobb számú sírt tártunk fel a kolostorudvar és a kerengő területén, amelyeket nagyobbrészt (de nem kizárólagosan) a szerzetesek temetkezésének tarthatunk. A monostortemplom és a templomtól északra lévő plébániatemplom között, illetve a plébániatemplom körül a monostor melletti falu temetőjét valószínűsítetjük. Ezt a területet mi nem kutattuk, a 60 -as években több egymást is felülrétegző sírt tártak itt fel. ${ }^{50} \mathrm{~A}$ sírok értékelését megnehezíti, hogy a területre már a monostor alapítása előtt is temetkeztek.

Úgy tünik kezdetben a szerzeteseket a templomtól délre, délkeletre temették, erre utal a kolostorudvar északi részén és az északi kerengőfolyosóban talált nagyszámú temetkezés. Bár antropológia vizsgálat még nem történt, annyit elmondhatunk, hogy nagy arányban felnőtt férfiak melléklet nélküli sírjainak tünnek. A sírok metszik egymást, a korábbi sírok szétásásakor talált csontokat sokszor a sír északi szélére pakolták, ezt gyakran az anatómiai rendet valamennyire tartva, a koponyákat nyugatra helyezve tették. Előfordult, hogy az elhunyt feje alá téglát tettek. (24. ábra)

A területen viszonylag nagy számban tártunk fel téglakeretes temetkezéseket, összesen 21 ilyen sírt vagy sírrészletet sikerült azonosítanunk (23., 25. ábra). Téglalap vagy trapéz alakúak voltak, a több sorban rakott téglák között néhol csak földréteg volt, máskor gondosan habarcsba falazták ezeket. Előfordult, hogy a belső habarcsozáson meszelés nyoma is megfigyelhető volt. Többször a sírok tetejének nyomát is megtaláltuk, egy kissé kintebb csúsztatott téglának támasztva, sátortetőszerűen fedték ezeket a téglasírokat. A 60-as években feltártak egy kőlappal fedett, igen mély falazott sírt.

A téglakeretes temetkezések viszonylag elterjedtek a középkorban, a 11. századtól előfordulnak falusi plébániák és monostorok templomaiban és temetőiben is. ${ }^{51}$ A monostortemplomok déli oldalán gyakran tárnak fel hasonló, épített sírokat, amelyeket általában rangosabb temetkezésekként értelmeznek, ${ }^{52}$ ugyanakkor tudjuk, hogy szerzetesek is gyakorolták e szokást. ${ }^{53}$ A melléklet nél-

50 A plébániatemplomot a 13. század második felétöl keltezik. Annak megválaszolásában, hogy megépülte előtt hová temetkeztek, illetve hogyan változott a temetkezés rendje a temető nagyobb részletének feltárása segíthetne.

51 Papp 2002.,

52 Ritoók 1997. 169-170.

53 Papp 2002. 188. 
küli temetkezések nehezen datálhatóak, de a nagyobb részüket késöbbi sírok, alapfalak, akár többszörösen is rombolták, többségüket így nagy valószínüséggel az Árpád-korra, többet egyértelmüen annak korai időszakára keltezhetünk. Ugyanakkor néhány téglakeretes sír felülrétegez korábbi temetkezést, így a szokás viszonylag hosszabb ideig (legalább az Árpád-kor folyamán) használatban volt. A téglakeretes sírok a templomtól délre, délkeletre lévő területen koncentrálódtak, a kolostorudvar déli részén mindössze egy ilyen volt és a templomban is mindössze egy, a későbbi sírok által rombolt téglakeret maradványát találtuk meg.

A kerengő alapfalai számos sírt romboltak, elsősorban a templomtól délre, ahol a korábbi sírok sürüsödtek. (25. ábra) A nyugati kerengőfolyosóban, részben a kerengő kisebb területen megmaradt padlója alatt, két négyzet alakú gödörben eltemetett csontokat, feltehetően az építkezéskor rombolt temetkezések maradványait találtuk. Számos sírt viszont a 15-16. században a már elkészült kerengőbe ástak, annak falaihoz igazodtak, nagyjából sort alkotnak.

Több nyomát találtuk annak, hogy a monostor pusztulása után is temetkeztek a területre, legalább három ilyen sírunk van, kettő keletelt, a harmadik észak-déli tájolású.

\section{A leletanyag}

A feltárás során jelentősen bővült a 60 -as években kiásott leletanyag. A nagyszámú használati tárgy (kerámiaedények és kályhaszemek töredékei, sarkantyú, zabla, kés, szögek stb.) mellett a sírokból és szórványként viseleti tárgyak, ékszerek (gyürük, csatok, köpüs záródású karika, kapcsok stb.), könyvveretek, valamint nagyszámú római és középkori pénz is elökerült (12. ábra). A kőanyag is több szép darabbal, bordával, oszloptörzzsel, sírkővel gyarapodott. A legszebb leletünk egy arany ékszer darabja (12 ábra/1.). A finom kidolgozású, levágott sarkú kocka (kuboktaéder) alakú, filigrános díszű aranytárgy sajnos a 60-as években már átforgatott földben volt, így eredeti helye nem meghatározható. Az 1960-as és 2010-es években talált leletanyag feldolgozása egyszerre történik, remélhetőleg egy jövőbeni nagyobb terjedelmű publikációban részletes közlésre kerül. ${ }^{54}$

Kaposvár város önkormányzata a romterület rendbetétele, részleges helyreállítása mellett egy látogató központ építését is tervezi, amelyben egy kiállítás mutatja majd be a monostor történetét és az itt talált leletanyagot.

\section{Irodalom}

M. ARADI CsILLA 2016: Somogy megye Árpád-kori és középkori egyházszervezetének rekonstrukciója. Kaposvár 2016.

Bodó BALÁZs 2010: A pécsváradi bencés monostor építéstörténete az újabb kutatások tükrében (The Architectural History of the Benedictine Monastery at Pécsvárad as Reflected in the Latest Research). In: Benkő, Elek és Kovács, Gyöngyi (szerk.): A középkor és a kora újkor régészete Magyarországon (Archaeology of the Middle Ages and the Early Modern Period in Hungary). MTA Régészeti Intézete, Budapest. 2010. 349-386.

BuzÁs Gergely 2018: Atha comes kaposszentjakabi temploma. Archeologia - Altum Castrum Online 2018. http://archeologia. hu/content/archeologia/516/buzas-kaposszentjakab.pdf

BuZÁs GERgely - MÉszÁROS ORSOLYA 2008: A középkori Visegrád egyházainak régészeti kutatásai. - Magyar Sion (Új folyam) 44(2): 71-103.

GYőRFFY GYÖRGY 1975: Kaposvár az Árpád-korban. In: Kanyar József (szerk.): Kaposvár. Várostörténeti tanulmányok. Kaposvár 1975. 63-73.

HeRVAY F. LeVEnTE: 2001: Bencések és apátságaik a középkori Magyarországon. In: Takács Imre (szerk.): Paradisum Plantavit. Bencés monostorok a középkori Magyarországon. Kiállítási katalógus. Pannonhalma, Bencés Föapátság. 461-567.

H. GYÜRKI KATALIN 1981: Das mittelalterliche Dominikanerkloster in Buda. Fontes Archaeologici Hungariae. Budapest 1981.

H. GYÜRKı KATALIN 1996: A Buda melletti Kánai apátság feltárása (Die Freilegung der Kánaer Abtei bei Ofen). Budapest 1996.

HOLL IMRE 1975: A kaposszentjakabi kályhacsempék. (Ofenkacheln von Szentjakab). Somogyi Múzeumok Közleményei II. 1975.
JUHÁSz IRÉN 2000: A Csolt nemzetség monostora. In: Kolláth Tibor (Szerk.): A középkori Dél Alföld és Szer. Szeged 2000. 281304.

KoMJÁTHY MıKLós 1975: A középkorvégi Kaposvár. In: Kanyar József (Szerk.): Kaposvár. Várostörténeti tanulmányok. Kaposvár 1975. 75-92.

KozÁK KÁROLY 1981: Az egri és a pécsváradi vár (kolostor) XV-XVI. századi kemencéi. In: Gömöri János (Szerk.): Iparrégészeti kutatások Magyarországon. Égetőkemencék régészeti és interdiszciplinális kutatása. Veszprém 1981. 133-141.

KozÁK KÁRoly 1990: Az egri vár feltárása VII. 1957-1988 (Die Erschlineßsung der Burg Eger VII.) Agria 25-26 (1989-1990) 317-375.

KUMOROVITZ L. BERNÁTH 1964: A Zselincszentjakabi alapítólevél 1061-ből. („Pest” legkorábbi említése (Die Stiftungsurkunde von Zselicszentjakab aus dem jahre 1061.). Tanulmányok Budapest Múltjából XVI. Budapest. 1964. 43-83.

MAGYAR KÁLMÁN 1981: Kaposszentjakab. Bencés apátság romjai. Tájak, Korok, Múzeumok Kiskönyvtára, 68. Bp. 1981

MEZŐSINÉ KovÁcs ÉVA 1994: A vértesszentkereszti apátság a dominikánusok idején. (The Abbey of Vértesszentkereszt at the time (of) Its Dominician Occupancy). In: Haris Andrea (szerk.): Koldulórendi építészet a középkori Magyarországon. Múvészettörténet-Műemlékvédelem 7. 305-330.

MinAJlov, KIRILl AleksZeJeVics 2010: Реконструкция древнейших укреплений Старокиевского городища. (Rekonstruction of earliest fortification elements on the old Kyiv site of ancient settlement.) In: Археологія і давня історія України 1. Київ 2010, 308-315.)

54 A lelöhely érmeit és fémanyagát Varga Máté, a korai kerámiát Merva Szabina, a kolostor kerámiaanyagát Kristóf Virág, a kőanyagot Buzás Gergely dolgozza fel. A leletanyagból eddig az itt talált kőanyag egy része (Nagy 1973, Nagy 1978, Buzás 2018.) egy napóra töredéke (Varga 2014.), könyvveretek (Ujhelyi - Varga 2017) és két kályhacsempe (Holl 1975.) került közlésre. 


\section{ÚJABB KUTATÁS A KAPOSSZENTJAKABI APÁTSÁG TERÜLETÉN 2. A 2016-BAN VÉGZETT RÉGÉSZETI FELTÁRÁS}

MoRDOVIN MAXIM 2013: A honti ispánsági vár kutatása 2011-ben. Communicationes Archaeologicae Hungariae 2010-13. 123-149.

NAGY EMESE 1973: Elözetes jelentés a kaposszentjakabi ásatásról (Rapport préliminaire sur les fouilles de l'abbaye de Kaposszentjakab). Somogyi Múzeumok Közleményei 1, 335-339.

NAGY EMESE 1978: Kaposszentjakab. In: Tóth Melinda - Marosi Ernő (Szerk.): Árpád-kori kőfaragványok. Székesfehérvár. A Székesfehérvári István király Múzeum Közleményei D sorozat 121. sz. Székesfehérvár. 1978. 91-92.

NAGY EMESE 1994: Zselicszentjakab. In.: Mikó Árpád - Takács Imre (Szerk.): Pannonia Regia. Müvészet a Dunántúlon. Budapest. 1994. 71-72.

OROSZ KRISZTINA 2010: Várak és kolostorok konyhái Magyarországon. (Kitchens of castles and monasteries in medieval Hungary) In: Benkő, Elek és Kovács, Gyöngyi (szerk.) A középkor és a kora újkor régészete Magyarországon (Archaeology of the Middle Ages and the Early Modern Period in Hungary). MTA Régészeti Intézete, Budapest. 2010. 561-596.

PÁvAI ÉVA 2000: Ellésmonostor kutatása. In: Kolláth Tibor (Szerk.): A középkori Dél Alföld és Szer. Szeged 2000. 219-232.

PAPP ILDIKó KATALIN 2002: Téglás és téglakeretes temetkezések az Alföldön (Gräber mit Ziegeln und Ziegelrahmen in fer südöstlichen Tiefebebe). Cummunicationes Archealogicae Hungariae 2002. 177-194.

P. HARTYÁNI BORBÁLA - NovÁKI GYULA 1975: Növényi mag és termésleletek Magyarországon az újkőkortól a XVIII. századig In. Magyar Mezőgazdasági Múzeum közleményei 1973-74. Budapest 1975.

RITOÓK ÁGNES 1997: A magyarországi falusi templom körüli temetők feltárásának újabb eredményei (Latest results of exavation of village Churchyards in Hungary). Folia Archaeologica 46. (1997) 165-177.

SzŐKE BÉLA MıKLós 2007: A Balaton déli partvidéke és a Dél-Dunántúl a népvándorlás korában. 5-9. század. In: Belényesy K. - Honti Sz. - Kiss V. (szerk.): Gördülő idő. Régészeti feltárások az M7es autópálya Somogy megyei szakaszán Zamárdi és Ordacsehi között. 2007. 47-54
SZAKÁcS BÉLA ZSOLT 2015: Bizánc peremén: rendi hovatartozás és térelrendezés korai monasztikus építészetünkben. (Ont eh Borderlines of Byzantinum: Religius Affliation and Architectural Arrangement in Early Hungarian Monastic Architecture.) In: Keleti keresztény kultúra határainkon innen és túl. A 2012. november 09-én rendezett konferencia tanulmányai (szerk: Bojtos Anna) 166-179.

SzIMONOVA EUGENIA 1997: A toponári avar temető. In.: Karacz G. (szerk.): Avarok és honfoglaló magyarok Somogyban. KGRE BTK TTL Marcali, 1997. 25-52. Bárdos 1978.

UJHELYı NÓRA - VARGA MÁTÉ 2017: Egy különleges könyvveret a kaposszentjakabi apátságból. Archeologia - Altum Castrum Online 2017. http://archeologia.hu/content/archeologia/489/ ujhelyi-varga-szentjakabi-konyvveret.pdf

VALTER ILONA 1982: A pásztói monostor feltárása. (Die Frieilegung des Klosters von Pásztó) Communicationes Archaeologicae Hungariae 1982. 167-206.

VARGA MÁTÉ 2014: Középkori napóra a kaposszentjakabi bencés apátságból (Medieval Sundial from the Benedictine Monastery of Kaposszentjakab) In: Rácz Tibor Ákos (szerk.): A múltnak kútja. Fiatal középkoros régészek $\mathrm{V}$. konferenciájának tanulmánykötete. 89-98., 375.

TAKÁCS MIKLós 2014. A magyarországi, 11. századi, ortodox monostortemplomok térszerkezete. (Raumstruktur der ortodoxen Klosterkirchen im Ungarn des 11. Jahrhundert). In A Kárpát-medence, a magyarság és Bizánc. Acta Universiatis Szegediensis Opuscula Byzantina XI. (szerk: Olajos Terézia) 292-323.

TÓTH ENDRE - BuzÁs GERgely 2016: Magyar Építészet 1. A rómaiaktól Buda elfoglalásáig (A kezdetektől 1541-ig) Budapest 2016.

ZÁDOR MıHÁLY 1964: Kaposvár. Budapest. 1964. 


\title{
Research in the area of the Benedictine abbey, Kaposszentjakab Part 2.
}

\author{
ISTVÁN MOLNÁR
}

The ruins of the Benedictine monastery at Kaposszentjakab are situated East from Kaposvár. The medieval monastery was earlier referred to as Zselicszetjak$\mathrm{ab}$ and was founded by Atha comes in 1061. Its letter of foundation survived and from this we know that at the time of the foundation already an old, ruined church stood on the territory. The monastery was devastated under the Turks. Its excavation was directed by Emese Nagy between 1960 and 1966. During 2014 the church, while in 2016 the larger part of the monastery was reexcavated.

In 2014 we found the remains of the old church already present at the time of the foundation. The church was $7,5 \times 12-13 \mathrm{~m}$ in area and had a single nave and square sanctuary. Its walls were reused in the monastic church. A cemetery encircled it as the later walls cut some of the burials. We conducted radiocarbon age definition on 3 bones from these burials which produced a date falling between the 8 and 9 C. In 2016 we excavated the remains of a fortification of a similar age as the church. The fortification built on a steep hillside through step formed berms with relatively narrow wooden frame filled with earth and attached to the berms by horizontal beams. The radiocarbon age definition conducted on parts of the burnt wooden frame and botanical remains burnt at the time of the devastation, the fortification cannot be dated earlier then the 8 C. while its decay happened before the last third of the
$10 \mathrm{C}$. The bems of the destroyed banks were reused by furnaces. Archaeomagnetic measurements dated them to turn of the $9 / 10 \mathrm{C}$. With the help of this data the devastation of the earthworks can be further narrowed.

The 18,5×12,5 meter large church built in the 1060-s was an edifice articulated by lisena strips from the outside and had a semicircular apse. In its middle range 4 pillars held a tower over a vaulted space. Towards its northern and southern sections side aisles with galleries were built, while above the western gallery a tower or twin towers stood.

We could trace the remains of monastic edifices built before the construction of the quadrum. The earlier building had two rooms and stood in the later southern wing. It was $6 \mathrm{~m}$ wide and at least 10-12 m long. We found the remains of another edifice about $6 \times 17 \mathrm{~m}$ which was divided into two in the western wing which was attached to the church. Its southern room was heated by a hypocaustrum. In the turn of the 13-14 C. in the eastern wing a $8,3 \mathrm{~m}$ long chapel with square sanctuary was placed lower in the hillside

The quadrum was constructed at the turn of the 14$15 \mathrm{C}$. following a fire. The earlier buildings were incorporated, while for the construction of the eastern wing the hillside was uploaded. A somewhat trapezoid court was created with vaulted arcade. The monastic church was also rebuilt and vaulted. During the 1540-s the monastery was transformed into a fortress. 